Article

\title{
Towards a Smart and Sustainable City with the Involvement of Public Participation-The Case of Wroclaw
}

\author{
Dorota Bednarska-Olejniczak $^{1}\left[\right.$, Jarosław Olejniczak ${ }^{2, *}$ (I) and Libuše Svobodová ${ }^{3}$ \\ 1 Department of Marketing Management, Faculty of Economic Sciences, Wroclaw University of Economics, \\ 53-345 Wrocław, Poland; dorota.olejniczak@ue.wroc.pl \\ 2 Department of Finance, Faculty of Economic Sciences, Wroclaw University of Economics, \\ 53-345 Wrocław, Poland \\ 3 Department of Economics, Faculty of Informatics and Management, University of Hradec Kralove, \\ 50003 Hradec Králové, Czech Republic; libuse.svobodova@uhk.cz \\ * Correspondence: jaroslaw.olejniczak@ue.wroc.pl; Tel.: +48-600-627-623
}

Received: 29 November 2018; Accepted: 2 January 2019; Published: 10 January 2019

\begin{abstract}
The purpose of this article is to identify the directions and scope of inclusion of the residents participation into the concept of city's sustainable development and the smart city concept, taking into account national and international conditions, on the basis of Wroclaw's practices in 1998-2018. Many researchers have emphasized the necessity of including residents' participation in both the smart city concept and the sustainable city development concept, but they do not focus on a coherent linking of these activities during evolution toward a sustainable smart city (SSC). The in-depth case study analysis considered, i.e., three subsequent Wroclaw development strategies (1998-2018) and implementation of the smart city concept in Wroclaw (2015-2018) with particular emphasis on the issue of public participation and sustainable development of the city. The results of study show that in the case of the developments in the activities of smart city and sustainable city development carried out by Wroclaw, it is possible to identify two different approaches to residents' participation in city activities. In Wroclaw, 'residents' participation' in the framework of the sustainable city development activities currently covers all theoretical levels of participation, while within the smart city activities it focuses mainly on the participatory budget and the limited use of ICT. The conducted research indicates that for the implementation of the SSC concept it would be important to integrate these approaches in order to ensure the full range of residents' participation in accordance with theoretical postulates. The conducted analysis therefore covers mostly unexplored area of research, which is important from the point of view of a city's evolution toward becoming a sustainable smart city. The conclusions from the research are also an empirical contribution to the analysis of the changes of cities towards SSC and indicate the need for further, extended research on the undertaken problem.
\end{abstract}

Keywords: city sustainable development; smart city implementation concept; residents' participation; participatory budgeting; Wroclaw 1998-2018

\section{Introduction}

Public participation with the use of participatory budget as one of the 'tools' has become, in the recent years, a very important element of the decision-making process in the scope of activities aimed at improving the quality of city residents' life, in developing countries, as well as in developed countries [1-6]. In the 1990s, the need to use public participation was indicated in the scope of shaping public spending directions. Litvack and Seddon indicated that "local referendums, permanent public-private councils, and other institutional structures are other easily identifiable conditions 
that may improve the ability of local governments to identify and act on citizen preferences" [7] (p. 16). The public participation itself may include a very wide range of activities focused on various stakeholders [8-10] (i.e., residents, non-profits, businesses) and their roles (e.g., as advisory boards for social issues or development in planning, in supporting city management, in design new apps or trough participating in public decisions) in supporting smartization process [11], however in this work the focus will be placed on the consistency of the residents' participation (with particular emphasis on participatory budgeting (PB) with the concept of smart city and sustainable development (SD) of city on the example of Wroclaw. The reason for undertaking this research problem is on the one hand the observed in Poland's adaptation of public participation, particularly PB, to the urban development strategies (usually strongly embedded in the purposes of sustainable development), and on the other hand, a small number of publications analyzing this last problem [12-15]. Literature devoted to the public participation in the context of sustainable urban development usually includes selected elements of areas of the sustainable development (equity and social justice, economic development, environmental protection, urban governance) [12,16-21]. Examples of holistic approach to the issue of SD in the cities include among others: collective work of the Public Participation in Sustainability Science: A Handbook [22], Campbell's Planner's Triangle Model [23] indicating possible conflicts and ways to solve them (also with the inclusion of the negotiations and referendums with social groups), or the article by Weymouth and Hartz-Karp [24]. The literature emphasizes the role of public participation in the aspect of governance [25-29], while the analysis of the significance of public participation in the smart city concept cannot be found so often $[13,30,31]$. Also noteworthy is the concept of deliberative collaborative governance (DCG) and PB is one of its elements [27]. The purpose of this article is to try to identify the directions and scope of inclusion of the public participation into the concept of city's sustainable development and the smart city concept, taking into account national and international conditions, on the basis of Wroclaw's practices in 1998-2018. The time frames were determined by the dates of adopting subsequent development strategies by the city. This attempt is important due to the fact that in Polish conditions, the activities undertaken by cities aimed at harmonious combination of actions oriented to sustainable city development with the implementation of the smart city concept, have not been analyzed so far, particularly taking into account public participation in these two areas. In this context, the case of Wroclaw may constitute a relatively modest supplementation of the existing achievements of science associated with the sustainable smart city concept. The conducted analysis, apart from explaining the conditions of evolution in the approach to public participation and sustainable development from the perspective of creating and implementing city development strategies, contributes to the determination of the possibilities and limitations of adapting these actions into the practical implementation of the sustainable smart city concept. Simultaneously, the additional effect of the conducted analysis is the indication of the relations between the implementation of smart city solutions and sustainable city development. It also contributes to the sustainable and smart cities debate by adding empirical support to sustainable smart city concept and points out a largely unexplored area of research.

\section{State of the Art}

\subsection{The Concept and Sources of Sustainable Development}

Sustainable development (SD) is the main concept of global environmental policy [32-36]. Its main assumption is to ensure the possibility of society interaction with the environment, while reducing the risk of damaging the resource for the future. One of the most cited definitions of SD has been formulated in the report of the World Life Issues on Environment and Development (WCED) Commission led by G.H. Brundtland and entitled Our Common Future [37]. This commission indicated that "Humanity has the ability to make development sustainable to ensure that it meets the needs of the present without compromising the ability of future generations to meet their own needs" [37] (p. 16). It was also indicated here that economic and ecological goals should be linked to social goals. The latter 
are defined as fair opportunities of access to natural resources. As a result of noticed "failures of 'development' and failures in the management of our human environment", as well as "environmental trends that threaten to radically alter the planet" [37] (p. 10), the commission (among others) has been authorized to raise the levels of understanding and commitment to action of individuals, voluntary organizations, businesses, institutes, and governments.

From the point of view of this article, it is significant that this report indicates seven critical objectives connected with sustainable development [37] (p. 46): reviving growth; changing the quality of growth; meeting essential needs for jobs, food, energy, water, and sanitation; ensuring a sustainable level of population; conserving and enhancing the resource base: reorienting technology and managing risk; and merging environment and economics in decision making. In the commentary regarding the last objectives, the role of civil society participation was emphasized. It was indicated that "sustainability requires the enforcement of wider responsibilities for the impacts of decisions. This requires changes in the legal and institutional frameworks that will enforce the common interest (... ). The law alone cannot enforce the common interest. It principally needs community knowledge and support, which entails greater public participation in the decisions that affect the environment. This is best secured by decentralizing the management of resources upon which local communities depend, and giving these communities an effective say over the use of these resources. It will also require promoting citizens' initiatives, empowering people's organizations, and strengthening local democracy" [37] (p. 56). Additionally, it may be indicated that "when the environmental impact of a proposed project is particularly high, public scrutiny of the case should be mandatory and, wherever feasible, the decision should be subject to prior public approval, perhaps by referendum". In the conclusion regarding Chapter 2: Towards Sustainable Development, as the first element conditioning the pursuit of sustainable development, a political system that secures effective citizen participation in decision making is listed, which more clearly emphasized the significance of public participation in sustainable development.

The above-mentioned report has become one of the reasons for organizing the United Nations Conference on Environment and Development (Rio Earth Summit, 1992), during which the issues regarding SD were fundamental in the discussions. One of the effects of Rio Earth Summit was the development of Agenda 21 [38] —as the final document in which it was indicated that "sustainable development should become a priority item on the agenda of the international community" [38] (Chapter 2, sec.1). Agenda 21 also recommends that national strategies be developed to address economic, social and environmental aspects of sustainable development. In the SD context, at the local (also urban) level in the Chapter 28, Local authorities' initiatives in support of Agenda 21 (called also "local Agenda"), the issue of important role of local authorities is undertaken in the scope of fulfilling Agenda 21 objectives "because so many of the problems and solutions being addressed by Agenda 21 have their roots in local activities" [38] (Chapt. 28, sect. 1). This results from the fact that local authorities' competences include a number of tasks associated with the "constructing, operating and maintaining economic, social and environmental infrastructure, overseeing planning processes, establishing local environmental policies and regulations, and assisting in the implementation of national and subnational environmental policies". It is important to point out that the role of local authorities (and therefore also cities) was emphasized as the level of governance closest to the people, which should play a key role in influencing, through educating, mobilizing and responding to the public, on building a positive SD reception among citizens. The assumption is that the local authorities should use the dialogue with citizens and other local entities, which through consultation and consensus-building will enable to develop local development strategies adapted to the specificity of local communities that will be consisted with a local Agenda 21. It should be noted that during this period, we had early experiences in the scope of participatory budget (PB) (period of trials between 1989 and 1997, which highlighted the initiatives in Porto Alegre in Brazil, and Montevideo in Uruguay [39]), therefore, due to the low significance of $\mathrm{PB}$ in this period, it was not indicated as one of the SD instruments at the local level. Due to the fact that in the 90s of the XX century, the main partner 
of authorities, which enabled "participatory democracy" consisted of non-governmental organizations, it was decided that formal and informal organizations, as well as grass-roots movements, should be recognized as partners in the implementation of Agenda 21 [38].

As a consequence of the problems undertaken in the Agenda 21, the Millennium Development Goals (MDG) were adopted at the UN forum in 2000 [40]. The eight Millennium Goals were a commitment of the international community to (1) eradicate extreme poverty and hunger; (2) achieve universal primary education; (3) promote gender equality and empower women; (4) reduce child mortality; (5) improve maternal health; (6) combat HIV / AIDS, malaria and other diseases; (7) ensure environmental sustainability; and (8) develop a global partnership for development. The UN has set 18 targets and 48 indicators corresponding to these goals in order to monitor the implementation of MDGs at global, national and local levels [41]. It is easy to notice that the above-mentioned goals, targets, and indicators do not take into account the idea of civil society and its participation in activities for the benefit of sustainable development.

The literature indicates that the main area of Agenda 21 consisted of the environmental aspects of SD [42]. The conclusion of this focus on environmental aspects was the change, postulated by Drexhage and Murphy report [42], which is important from the viewpoint of this work, using partnerships between government, business and civil society to identify and test new approaches, and to scale up promising approaches [42]. Noticed dysfunctions in the implementation of Agenda 21 are associated with directing the implementation of activities to the environmental aspect (focus on the "environmental box"). During the summit entitled 2002 World Summit on Sustainable Development (WSSD), the main emphasis has been placed on the social and economic development [43]. Redclif [44] indicated that SD after the first Earth Summit (1992), focused on rights, rather than needs, as the principal line of enquiry. In this context, the question arises whether PB in the scope of SD is a tool associated more with the implementation of rights or the improvement of the quality of life, thus satisfaction of the needs.

Along with the arising criticism of MDG and Agenda 21, the UN has undertaken actions in order to introduce a new development strategy Transforming Our World: the 2030 Agenda for Sustainable Development [45]. The Development Agenda replaces the Millennium Development Goals adopted in 2000. Development of the Agenda assumptions was carried out through international negotiations coordinated within the United Nations by the High Level Panel (HLP) on the Post-2015 Development Agenda. HLP announced recommendation for the next global development plan, taking into account results of the report entitled A New Global Partnership: Eradicate Poverty and Transform Economies through Sustainable Development [46]. The agenda contains 17 Sustainable Development Goals and 169 targets associated with them, which are monitored with appropriate indicators. From the viewpoint of this article, it is important to indicate that within the Agenda 2030, "Make cities and human settlements inclusive, safe, resilient and sustainable" was distinguished as one of the goals (goal 11). Noticing the significant increase in the role of cities in the settlement network and the association problems, the UN indicated that within goal 11, apart from targets that are a kind of continuation of MDGs [41,45], the target 11.3 was indicated, which is supposed to enhance inclusive and sustainable urbanization and capacity for participatory, integrated, and sustainable human settlement planning and management in all countries. One of the indicators of this target is the proportion of cities with a direct participation structure of civil society in urban planning and management that operate regularly and democratically. This means that, compared to earlier solutions, the role of citizens' participation in sustainable development has been emphasized in Agenda 2030.

\subsection{Sustainable Development of Cities}

In the context of cities, SD has no single definition and it is understood in a very different way, depending on the approach presented by the researchers [47]. Considering SD from the viewpoint of subject issues of this article, it may be assumed that the essence of SD in relation to cities recognizes that "a sustainable city is one which succeeds in balancing economic, environmental, and socio-cultural 
progress through processes of active citizen participation" [48] (p. 2). At the same time, it is indicated that "a 'sustainable city" is organised so as to enable all its citizens to meet their own needs and to enhance their well-being without damaging the natural world or endangering the living conditions of other people, now or in the future." [49] (p. 13). It is also necessary to emphasize that from this viewpoint, the urban form "must be of a form and scale appropriate to walking, cycling and efficient public transport, and with a compactness that encourages social interaction" [50] (p. 12). A very important aspect emphasized in relation to the achievement of SD in cities is the assumption that it should be "[a] development that does not require resources beyond its environmental capacity, is equitable, promotes social justice, and is created through inclusive decision-making procedures" [51] (p. 3). At the European level, the concept of SD was also defined assuming that "sustainable development is development that delivers basic environmental, social and economic services to all residents of a community without threatening the viability of the natural, built and social systems upon which the delivery of these services depends." [52] (p. 8). Such approach results from noticing that sustainable development is much boarder concept than environmental protection. In the European Sustainable Cities-Report of the Expert Group on the Urban Environment, it was indicated that "it embraces concerns for the quality of life, for equity between people in the present, for inter-generational equity, and for the social and ethical dimensions of human welfare." [52] (p. 8). In conclusion regarding the report, it is emphasized that "the sustainable development agenda provides new challenges for urban policy integration within holistic frameworks" [52] (p. 8).

In the context of sustainable development of cities, it is also necessary to indicate that measures have been taken within the EU in order to determine the principles and strategies of urban development policy. The Leipzig Charter is usually considered to be the key (although not the only) document [53]. According to the preamble of the above-mentioned charter: The "Leipzig Charter on Sustainable European Cities" is a document of the Member States which has been drawn up with the broad and transparent participation of European Stakeholders." [53] (p. 1). Two key objectives have been determined within the Charter: (1) making greater use of integrated urban development policy approaches; (2) putting emphasis on deprived neighborhoods within the context of the city as a whole. Target-specific strategies have been defined for each goal. An overview of selected EU activities in the area of sustainable development is presented in the Table 1.

Table 1. Selected EU measures in the scope of sustainable development of cities.

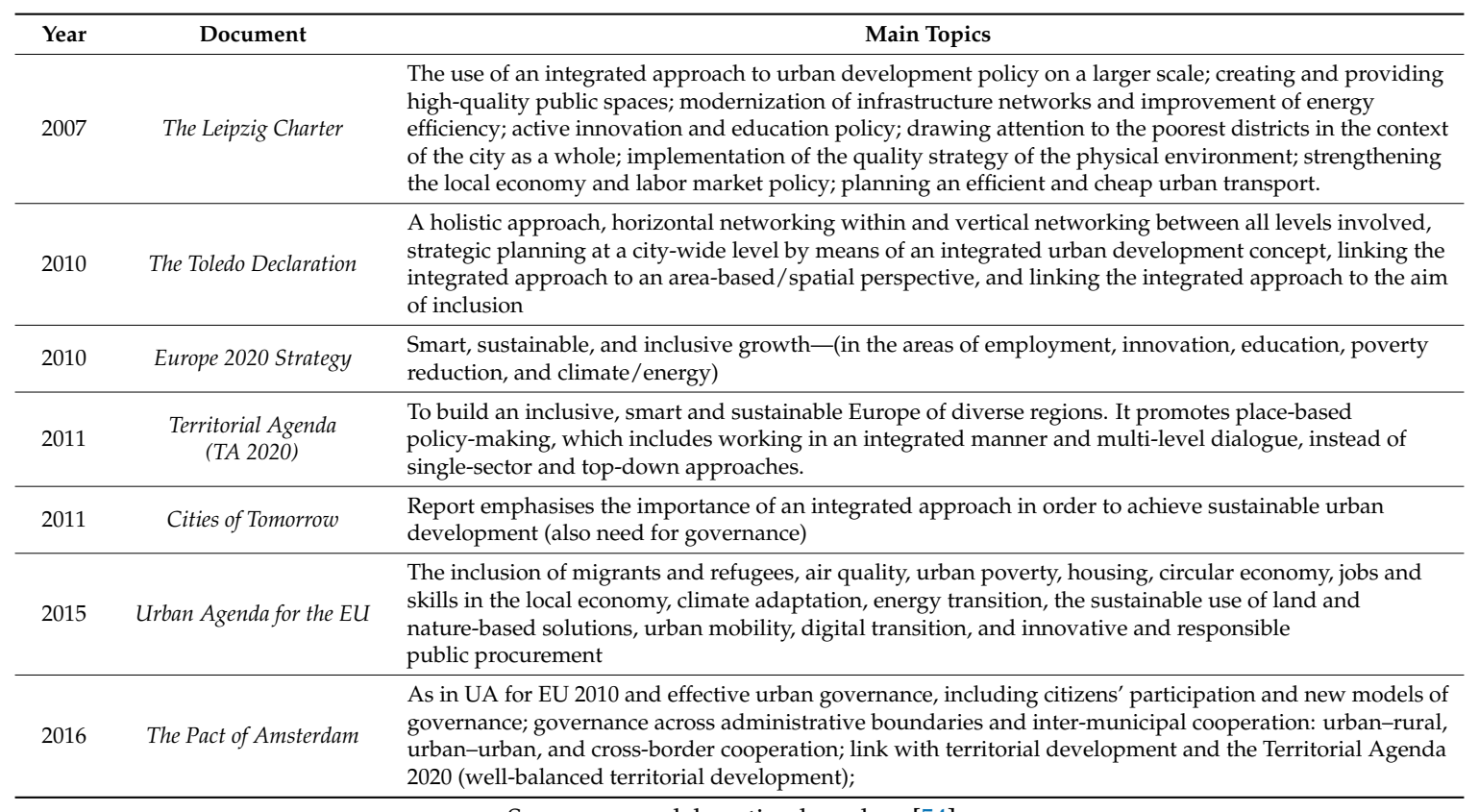




\subsection{Sustainable Development in Polish Cities in the Context of Selected Government Activities}

In the course of implementing the assumptions of Agenda 2030, Poland created in 2017 The Strategy for Responsible Development (SRD), which is supposed to reflect the national approach to the issues of sustainable and responsible economic development. This approach was determined as "responsible development". According to the provisions of this strategy, it means "one which, in the process of strengthening competitiveness by means of new growth factors, allows the participation of and provides benefits to all social groups living in various parts of our country [ ... ]. The focus is not solely on the total size of GDP, but rather on its quality as well as the perception of the development processes in the context of their importance for citizens" [55] (p. 27). The main goal of SRD was "to create conditions that foster income growth for all residents of Poland, while also increasing social, economic, environmental and territorial cohesion" [55] (p. 43). In the scope of this Strategy, three specific objectives related to individual goals of SDG were determined (Table 2).

Table 2. Main assumptions of SRD.

\begin{tabular}{|c|c|c|}
\hline \multicolumn{3}{|c|}{ Main Objective of the SRD } \\
\hline $\begin{array}{l}\text { Sustainable economic growth } \\
\text { increasingly driven by knowledge, } \\
\text { data, and organizational excellence }\end{array}$ & $\begin{array}{l}\text { Socially sensitive and territorially } \\
\text { sustainable development }\end{array}$ & $\begin{array}{l}\text { Effective state and economic institutions } \\
\text { contributing to growth as well as social and } \\
\text { economic inclusion }\end{array}$ \\
\hline SDG: $2,3,4,7,8,9,10,11,12,13,16,17$ & SDG: $1,2,3,4,5,6,8,9,10,11,16$ & SDG: $3,8,9,11,16,17$ \\
\hline
\end{tabular}

One of the intervention areas indicated in the SRD assumptions was (within specific objective II) strengthening of urban area development management, among others through developing and disseminating the principles of social participation in the management process, and also, in the case of areas threatened by marginalization, support for local initiatives and stimulation of activity of local communities at the commune level, in the scope of building a civil society and supporting local leaders (initiatives within the Sołecki Fund (Community Fund), participatory budgets, local crowdfunding programs), development of social participation in the process of local development management (e.g., the promotion of good practices) [56]. In the report entitled Implementation of the Sustainable Development Goals in Poland [57], the national SDG achievement priorities were indicated. The basic goals include in this case, among others, switching from an administration system to governance. Also, the analysis of convergence of the SRD priority areas with the goals and targets of the 2030 Agenda was carried out. The following areas were recognized as the ones with the highest convergence: education, participation, social inclusion, GDP growth, financial services, infrastructure, research and development, economic innovation, entrepreneurship, employment, sustainable agriculture, industry, adaptation to climate change, and pollution. Activities in the scope of urban policy in Poland are focused on the improvement of the development conditions of Polish cities, and the first of them is the dissemination of the principles of public participation in decision-making and management of cities and their functional areas. The above-mentioned activities include the project initiated by the Ministry of Development entitled Human Smart Cities-smart cities co-created by the inhabitants [58]. Among others, this project includes the thematic area defined as "Innovative solutions aimed at supporting the social participation, as an element necessary for an intelligent city co-created by the inhabitants (3.0 Human Smart City)" [59]. 
The above-mentioned activities are consisted with the priorities of a National Urban Policy 2023 (NUP) [60], created in 2015, where the necessity of public participation (including municipal-level dialogue and public consultations in the development process) is one of the highlighted thematic areas. The goal of the NUP is to strengthen the capacity of cities and urbanized areas for sustainable development and job creation, as well as improving the quality of life of the residents. Five specific objectives relating to the basic issue areas and contributing to the achievement of the strategic objective have been indicated [60]: (1) efficient (creating conditions for efficient, effective and partner management of development in urban areas, including especially in metropolitan areas); (2) compact and sustainable (supporting sustainable development of urban centers, including counteracting negative phenomena of uncontrolled suburbanization); (3) coherent (reconstruction of the development potential by regeneration of socially, economically and physically degraded urban areas); (4) competitive (improved competitiveness and potential to create development, growth and jobs of major urban centers); (5) strong (support for development of subregional and local urban centers, primarily in problem areas of regional policy (and in certain rural areas) by strengthening their functions and counteracting their economic collapse).

It should be emphasized that the NUP very strongly underlines the importance of public participation in the implementation of each of these goals, while its importance in the first goal is emphasized in the strongest manner. In regard to the participation, the consultations with citizens are indicated as the main process-where the following are recognized as the basic tools: participative budgets, civic legislative initiative, activating measures (picnics, cultural activities etc.), survey research, study works (workshops, laboratories, joint projects, PPGIS), on-line consultations).

From the viewpoint of this work, it is necessary to note the connection indicated in the NUP between the proposed urban policy and the smart city concept. NUP's authors directly indicate that the main idea of NUP "can be naturally identified with the concept of smart cities in its broadest, not narrow, industry understanding" [60] (p. 15). It is also emphasized here that the technological sphere must be accompanied by "intelligent" activities in other spheres of functioning, while "wisdom" of the city is expressed in an integrated approach to planning and transforming the city, as well as managing it. In accordance with the provisions of NUP, the cities should actively seek and then apply solutions enabling the rationalization of expenses, more effective management of various aspects of the city's functioning, as well as more precise and faster reacting to the diagnosed problems. In the opinion of NUP's authors, only such view of the 'learning' city allows to qualify the city as a smart city. This approach also indicates the method for measuring success-the primary measure will be the constantly increasing quality of the residents' life.

\subsection{The Concept of Smart City and Smart Sustainable City}

The concept of a smart city appeared in 1997 (Graham and Aurigi [61,62]), along with the increase in the possibility of using ICT tools for communicating with residents, collecting data or using this data to manage the city. It is difficult to indicate one universal definition of the concept of a smart city. In 2000, Hall et al. indicated that "a city that monitors and integrates conditions of all of its critical infrastructures, including roads, bridges, tunnels, rails, subways, airports, seaports, communications, water, power, even major buildings, can better optimize its resources, plan its preventive maintenance activities, and monitor security aspects while maximizing services to its citizen" [63] (p. 1). Therefore, 'smart city' in this definition was associated with the use of ICT to support the delivery of public services. In Komninos' definition from 2006 (cited quite often) a smart city is defined as "territories with high capacity for learning and innovation, which is built—in the creativity of their population, their institutions of knowledge creation, and their digital infrastructure for communication and knowledge management" [64] (p. 13). The idea of 'smart city' in the report entitled Smart Cities-Ranking of European Medium-Sized Cities is defined quite differently (more broadly), because it indicates that smart city is a city well performing in a forward-looking way in [..] six characteristics [economy, people, governance, mobility, environment, and living], built on the smart combination of endowments and 
activities of self-decisive, independent and aware citizen" [65] (p. 11). Caragliu et al. identifies smart city with the situation "when investments in human and social capital and traditional (transport) and modern (ICT) communication infrastructure fuel sustainable economic growth and a high quality of life, with a wise management of natural resources, through participatory governance." [66] (p. 71). The above-mentioned definition is largely based on the aforementioned six characteristics of smart city. It should be noted that the concept of participatory governance appears here in the context of smart city. Most definitions emphasize the importance of ICT in defining smart cities. Moreover, in practice, the multitude of approaches is visible similar to the concept of smart city, which translates into the use of alternative concepts resulting from highlighting the most important implementation areas in a given city. Anthopoulos and Fitsilis [67] separated seven groups of cities, apart from smart cities: (1) web (virtual) cities (focused mainly on provision of information, on-line communication capabilities and cyberspace); (2) knowledge cities (digital public repositories with crowd sourcing options accessible via ICT); (3) broadband cities/metropolies (with ultra-high speed networks in the urban area); (4) mobile cities (with wireless broadband networks accessible across the city); (5) digital/information cities (with ICT environment across the city for support of local needs and transactions, building local information society and creating sustainable local development); (6) ubiquitous cities (extension of the digital or information city in enabling ubiquitous service provision and data flow from anywhere to everyone, due to the use of chips or sensors built-in urban infrastructure); (7) eco cities (as ubiquitous cities focused on sustainable growth and for environmental protection). It is also worth noting that the definition used by the International Organization for Standardization [68] (p. 3), which indicates that smart city is "a new concept and a new model, which applies the new generation of information technologies, such as the internet of things, cloud computing, big data and space/geographical information integration, to facilitate the planning, construction, management and smart services of cities". At the same time, the following goals of smart city are emphasized [68]: convenience of the public services; delicacy of city management; liability of living environment; smartness of infrastructure; long-term effectiveness of network security. Analysis of smart city evolution was carried out by Cohen [69], who distinguished its three generations. In the smart city of the third generation, the initiative is taken over by city residents. The city authorities play the role of an assistant, observer or they support the process of communication.

From the viewpoint of this article, it should be noted that the concept of smart city can be also considered in terms of research issues undertaken by scientists. A holistic and interdisciplinary approach to the issue of SC research in the cities and villages is presented in papers of Visvizi and Lytras [70-72]. They argue [71] (p. 134) "that smart cities research needs to be based on real tangible experiences of individuals inhabiting rural and urban space and that it also needs to mirror and feed into policy-design and policymaking processes". Visvizi and Lytras notice also that [72] (p. 1) "the application and usability of ICT in the context of a village remained underdiscussed in the literature" introducing the idea of the 'smart village' into the debate. Annapoulos et al. [73] carried out a review and comparison of the smart city conceptualization models, indicating architecture, governance, planning and management, data and knowledge, facilities, services, people, and finally environment as occurring directions of conceptualization. It should be emphasized that the occurrence of a trend in the literature, which binds the smart city with governance, indicated in [73], due to the capacity of the governance concept may refer to various issues, depending on the author. The concept of governance is defined, for example, as "the process by which we collectively solve our problems and meet our society's needs" [74] (p. 24), while Pierre defines governance as "the process through which local authorities, in concert with private interests, seek to enhance collective goals. It is a process shaped by those systems of political, economic and social values from which the urban regime derives its legitimacy" [75] (p. 373). Stoker [76] (p. 18) indicated that it is possible to distinguish the following aspects of governance: (1) it refers to a set of institutions and actors that are drawn from but also beyond government; (2) it identifies the blurring of boundaries and responsibilities for tackling social and economic issues; (3) it identifies the power dependence involved in the relationships between 
institutions involved in collective action; (4) it is about autonomous self-governing networks of actors; (5) it recognizes the capacity to get things done which does not rest on the power of government to command or use its authority. It sees government as able to use new tools and techniques to steer and guide. It is noticeable that citizen participation appears in the context of governance. There are many analyses that take into account the role of participatory governance (PG) and citizen involvement in the concept of smart city [65,77-80]. The PG itself may apply to many areas. For example, based on the review of literature dealing with the topics of PG mechanisms in developing countries, Speer [81] identified four main strands to use for partitioning the literature: (1) the democratic decentralization strand, (2) the deliberative democracy strand, (3) the empowerment strand, (4) the self-governance strand. As a consequence, the inclusion of the governance area in the concept of smart city may, among others due to participation, support the process of good governance by making it more efficient, fair, transparent, and legal. In accordance with the UN concept, the good governance is supposed to be characterized by the following eight basic characteristics: participatory, consensus oriented, accountable, transparent, responsive, effective and efficient, equitable and inclusive and follows the rule of law [82]. In 2008, the Council of Europe [83] identified 12 principles of good governance at local level. They include: fair conduct of elections, representation, and participation; responsiveness; efficiency and effectiveness; openness and transparency; rule of law; ethical conduct; competence and capacity; innovation and openness to change; sustainability and long-term orientation; sound financial management; human rights; cultural diversity and social cohesion; accountability. The implementation of most of the above-mentioned principles can be supported, which is easy to notice, due to implementation of the concept of smart city. It should be also noted that by many researchers recognized the implementation of good governance as one of the conditions of successful economic development [84].

The concept of smart sustainable cities appears in the source literature as an effect of parallel occurrence in practice, within one city of activities in the framework of sustainable city development and the adoption of solutions in the scope of smart city [30,85-89]. The problem in defining a smart sustainable city lies primarily in the lack of coherence within both concepts, as well as in the fact that they are overlapping. UN Economic Comission and ITU define smart sustainable city as innovative city "that uses information and communication technologies (ICTs) and other means to improve quality of life, efficiency of urban operation and services, and competitiveness, while ensuring that it meets the needs of present and future generations with respect to economic, social, environmental as well as cultural aspects" [90]. Sometimes, the role of smart city in sustainable development is also indicated-"the smart city with its digitally mediated, efficient and integrated infrastructure is positioned as a facilitator of sustainable development by aligning the aims of environmental protection, social equity and economic development" [91] (p. 271). Whereas, Bibri [92] indicated that the concept of 'smart sustainable city' is used to describe a city that is supported by the pervasive presence and massive use of advanced ICT, which, in connection with various urban systems and domains and how these intricately interrelate and are coordinated respectively, enable the city to control available resources safely, sustainably, and efficiently to improve economic and societal outcomes. Höjer and Wangel [93] (p. 344) point out that "cities can be made sustainable without the use of smart (ICT) technology, and smart technologies can be used in cities without contributing to sustainable development. [ ... ]. It is only when all these three aspects are combined, when smart technologies are used for making cities more sustainable, that we can speak of Smart Sustainable Cities". On the other side, in a recent in-depth literature review D'Auria and co-authors [94] (p. 11) indicate that in the literature "often [ ... ] the sustainable city is considered an evolution or an advanced version of the smart city". Authors underline that smart city conception is an evolution of a digital city concept (by adding to ICT and innovation "human features of city life") and next they define the sustainable city concept as "a new approach [to smart city] through the filter of a new philosophy" [94]. The main change is inclusion of an "equitable and balanced setting of goals in line with the principles of sustainable development" [94]. D'Auria et al. point that there are different elements of change and expected goals and that evolution 
from a digital city to the sustainable city should be described more as a "change" ("because it represents a suitable way to describe the evolution that cities have experienced in recent years, regardless of the perspective" [94]). They also notice that a smart city can be considered as a base for creating activities ensuring city sustainable development and that smartization process significantly supports "sustainable urban development" and improves "quality of life".

On the basis of conducted analyses, Dhingra and Chattopadhyay [95] (p. 551) indicate that it is possible to recognize a city as a smart sustainable city (SSC), when one of the seven important goals is "achieved in an adaptable, reliable, scalable, accessible and resilient manner". These goals include: (1) improve quality of life of its citizens; (2) ensure economic growth with better employment opportunities; (3) improve well-being of its citizens by ensuring access to social and community services; (4) establish an environmentally responsible and sustainable approach to development; (5) ensure efficient service delivery of basic services and infrastructure such as public transportation, water supply and drainage, telecommunication, and other utilities; (6) ability to address climate change and environmental issues; (7) provide an effective regulatory and local governance mechanism ensuring equitable policies.

In this context, the diagnosis of the SSC term's origin proposed by Nam and co-authors seems to be interesting [79]. Adding the word "smart" to sustainable city indicates that SSC "is required to adapt itself to the user needs and to provide customized interfaces" [79] (p. 283). The idea of using the (neoliberal) concept of a smart city in order to achieve sustainable development it is not uncritically accepted. It is subjected to criticism more and more often, because the possible tensions between SD and SC are indicated, which may include [91]: (1) reinforcing neoliberal economic growth; (2) focusing on more affluent populations; (3) disempowering and marginalizing citizens; (4) neglecting environmental protection; and, (5) failing to challenge prevailing consumerist cultures. Martin, Evans, and Karvonen indicate that in the some studies, there are doubts reported whether digitization can actually deliver sustainability, especially from the perspective of environmental protection and social equity [91]. From the viewpoint of this article, the third tension is significant-because an allegation appears in the literature that "rather than being empowered to participate in the smart city, citizens are instrumentalised as another efficient component of the digital infrastructure" [91] (after [96]). The authors of the above-mentioned analysis also indicated that increase in the role of "smart engagement could marginalise citizens further from practices of urban governance as global technology companies take responsibility for services previously provided by local government [91] (after $[86,97]$.). This may result from the fact notices by the researchers that "digital innovations have been designed based on the assumption that structural problems can be resolved through changes in the behaviour of individual citizens" [91] (p. 273). On the other hand, the analysis conducted by them indicates the communes' growing interest in regard to the use of ICT, in order to empower citizens and increase citizen inclusion in urban governance, whereas it should be noted that other innovations in the scope of citizen participation were also used within the smart city initiatives [91]. This is important, because it confirms that the concept of smart city is currently defined not only through the prism of using ICT.

\subsection{Participation and Participatory Budget}

Growth of the interest in public (citizen) participation since 1989 [39] is often associated with the hope of using various forms of cooperation between local authorities and residents, in order to better adapt public services to the needs reported by the residents $[1,12,20,84,98-102]$. Other goals of participation consist of social goals, such as [103]: (1) educating the public; (2) incorporating public values, assumptions, and preferences into decision making; (3) increasing the substantive quality of decisions; (4) fostering trust in institutions; (5) reducing conflict; and (6) making decisions cost-effectively. In the case of the last goal, it should be noted that it is a measure of the legitimacy of individual forms of social participation. Juxtaposition of the costs of individual types of participation with achievable or expected effects often provide the possibility of choosing a more favorable form 
of participation. In the context of this article, the concept of public participation will refer in a wide sense to enabling citizens to participate in the activities of public administration entities. However, the literature indicates a large variety of forms of such engagement of the citizens [104]. It is necessary to refer here to one of the first and most frequently cited method for determining the essence of social participation, proposed by Sherry R. Arnstein in 1969 [105]. In this concept, the participation refers to the influence of "minorities" on the decision of those who manage. The typology of participation types has been arranged hierarchically here, along with the increase of the decision-making power of stakeholders. Arnstein divided the participation levels into three groups. Firstly, nonparticipation (manipulation and therapy rungs); secondly, tokenism (information, consultation and placation); thirdly, citizen power (partnership, delegated power, citizen control). The lowest levels of this 'ladder'-manipulation and therapy do not constitute the real participation, because they are aimed at shaping attitudes of stakeholders by those who manage ('illusory participation'). Subsequent levels of participation-information, consultation, and placation-constitute only a small part of proper participation, because besides getting information about the implemented task, citizens are not able to influence their form (informing) or, despite listening to stakeholders, collecting surveys, conducting other studies, the authorities do not undertake actions aimed at implementing the collected suggestions (consultations) or there is no possibility of influencing the actual actions of the authorities by the representatives of stakeholders participating in the planning and implementation of tasks [106]. In the Arnstein's opinion, only from the level of partnership, through the delegation of power to the taking over of control over the actions, we will be dealing with real participation. Thus, in the case of partnership, in the process of negotiation and co-responsibility, the stakeholders are able to influence the decisions of those who govern. In turn, when introducing elements of delegating power, the stakeholders will mainly decide about the shape of a given project. Whereas, the full participation will mean taking control over a part of government activities in the relevant area. Classification proposed by Arnstein contributed to Connor's considerations, who proposed a new ladder of citizen participation in 1988 [107], indicating two groups of participants-general public and leaders. The essence of this approach was to consider a ladder of participation in terms of the possibility to mitigate the tensions/conflicts associated with the selection of a given project. In the case of this division, it should be pointed out that the division of participation levels into individual groups has been clearly identified. The general public participates through participation in education (the lowest level), information feedback, and consultation. In Connor's opinion, this means (which seems to be logical) that only few from this group will become leaders (analogically as in, e.g., politics, science, or sport), who will get the possibility of joint planning ("one window approach"), mediation, litigation and resolution/prevention. On the other hand, Wilcox [108] describes the problem of participation in three dimensions: levels of participation (information, consultation, deciding together, acting together, and supporting independent community initiatives), phases of participation (initiation, preparation, participation, and continuation), and the people involved (local groups, businesses, residents, activists, officers, politicians). In this approach, the actual participation of stakeholders may mean joint decision-making in the case of most people, as well as initiating or preparing actions in the case of 'leaders'. Different approach to participation is presented by Creighton [109]. Definition adopted by Creighton emphasizes that that public participation is a process by which public concerns, needs and values are incorporated into governmental and corporate decision-making procedures; it is a two-way communication and interaction that is guided by one general goal-better decisions supported by the public opinion [109]. Creighton emphasizes the continuity of communication process with the stakeholders, associated with its subsequent stages, usually following one after another (inform the public, listen to the public, engage in problem solving, develop agreements). Rowe and Frewer [110] also highlight the aspect of the flow of information between participants and sponsors (e.g., governmental or regulatory agency), distinguishing public communication (one-way information flow and no involvement of the public), public consultation (a process initiated by the sponsor and there is a public feedback understood as public opinion concerning a given issue), and 
public participation (information is exchanged between members of the public and the sponsors, dialogue and negotiations occur). A frequently cited division of participation is the division defined by the International Association of Public Participation (IAP2) [111], which distinguishes five levels of participation (inform, consult, involve, collaborate and empower), however it is necessary to indicate here the core values for public participation defined by IAP2. From our viewpoint, the following two are the most important: "public participation includes the promise that the public's contribution will influence the decision" and [it] "promotes sustainable decisions by recognizing and communicating the needs and interests of all participants, including decision makers" [111].

Depending on the participation level, different tools may be used. At the lowest levels, the following may be used for the purposes of informing: act sheets, websites, open house, exhibitions, leaflets, or participatory innovation platforms [112-115]. Along with the increase in the demand for feedback, the following may be used: public comment, focus groups, surveys, public meetings up to the forms, in which the citizens have the possibility of direct influence through citizen advisory committees, participatory decision-making (budgets), citizen juries etc. The participatory budget can be considered to be one of the most fully consistent participation tools in regard to the concept of governance. In the introduction to the book entitled Hope for Democracy: 30 Years of Participatory Budgeting Worldwide [5] (p. 3), Dias indicated, on the basis of observation from over 30 countries all over the world, that participatory budgeting processes: (1) emerged and developed in contexts of multiple crises and, in some cases, as a response to these crises (lack of trust in institutions and political elites, conflicts of various kinds, disasters, etc.) [ ... ]; (2) have a capacity for action and production of impacts proportional to their own dimension, which, in most cases, is limited or circumstantial; (3) have a "methodological and conceptual elasticity" that has allowed their adaptation to different contexts and for different purposes, residing in this particular one of the main success factors for a territorial extension as vast as the one recorded so far. Wampler [116] defines participatory budgeting as a decision-making process, in which residents/citizens discuss and negotiate the method of distribution of public funds. Goldfrank [117] notices that this process is open to any citizen, who wants to participate in it. It combines the forms of indirect and direct democracy, requires discussion and contributes to the redistribution of resources. While introducing us to the topic of PB, Shah [118] (p. 1) indicates that "it is a tool for educating, engaging, and empowering citizens and strengthening demand for good governance. The enhanced transparency and accountability that participatory budgeting creates can help reduce government inefficiency and curb clientelism, patronage, and corruption". A similar approach is indicated by Sintomer, Herzberg, and Rocke [3], who identify the key issues for PB: (1) there has to be discussion of the financial and/or budgetary dimension; (2) participation of those responsible for budgeting policy administration; (3) it has to be a repeated process (e.g., every year); (4) it must include some form of public deliberation; (5) some accountability on the output is required.

Usually, the following characteristics are indicated in the case of participatory budget in Poland [98,106,119]: basis for the functioning of PB is the local (commune) law, the initiator of such activities consists of local authorities, it is supposed to improve the quality of life through the implementation of actions reported and selected by residents, it is a continuous, cyclical process with a long-term horizon, involving a wide groups of residents and having an educational aspect. In 2018, it became a mandatory activity of large cities in Poland under national law. Article 5a of the Local Government Act (LGA) [120] determines that "local legislative bodies have the power to consult with local residents on major issues for the municipality". This results in the possibility of communes introducing social consultations, among others, concerning the directions, scale and methods of spending public funds. Unfortunately, the general nature of this regulation resulted in the fact that the introduction of PB in Poland encountered major problems, which include [119]: (1) total freedom of the local authorities in undertaking decisions on the conduct of consultations (of any kind); (2) great freedom of the local authorities as to the choice of formula of consultations; (3) lack of necessity to realize the selected by residents budgetary tasks for realization in the framework of the budget; (4) diverse scale of bottom-up disbursement of funds; (5) lack of formal separation of the 
participatory budget from the entity budget; (6) indication (selection) of the authorized participants of the consultation procedures; (7) pre-defined by local government authorities areas of expenditure. This resulted in an extensive diversification of scales and forms of the PB introduction as a participation form in the cities.

\section{Materials and Methods}

In this paper, the authors decided to analyze the role of public participation in the context of the development of the smart city concept, as well as the sustainable city concept with the use of Wroclaw qualitative single-case study. Bansal [121] (p. 127) indicates that "qualitative research is based on textual data, drawn from researchers' observations, interviews, analyses of archival manuscripts, and other similar sources". In the literature, case study is usually perceived as a research method that serves an in-depth examination of a single example of a class of phenomena. There is a dispute as to the meaning and possibility of using case study method in social sciences [122], but in order to understand a complex issue of a different approach to residents' participation, in-depth case-study research was necessary. The premise for undertaking research, was observed by the authors changes and differences in approaches to residents' participation in the strategies of sustainable city development and in the area of smart city implementation.

Wroclaw is situated in southwest part of Poland, between Berlin (300 km), Warsaw (300 km), and Prague $(220 \mathrm{~km})$. It is a capital of Lower Silesia voivodeship (region, NUTS-2). It is one of the medium-sized cities in Europe with a population of about 635,000 and it is also one of "second tier cities" [123]. Wroclaw covers an area of $293 \mathrm{~km}^{2}$ (more: [124]). Also, it is one of the main communication nodes of the south-western Poland (E-30 railway line, A4 motorway, S-5 and S-8 roads) and important communication artery of Europe. It is a city of science and education-there are 13 universities located here, including several of the highest national rank, as well as many significant cultural institutions, and it is a center of economic development, placed by analysts in the forefront of the most developing cities in Poland, while having the image of the center of growth area with European importance, as well as a city of diversified economy, various industries, rapidly growing sector of financial services, entrepreneurial services, and extensive transport services. The reason for selecting Wroclaw as the case of research is that the city met the following conditions:

- The existence of a city development strategy that takes into account sustainable development of the city and participation of residents;

- Undertaking by the city the activities in the smart city area within the framework of a policy defined by the city (not individual actions detached from each other), including the role and forms of participation of residents and sustainable development of the city;

- The existence of defined different forms of participation within both areas;

- Relatively long period of co-existence of strategy, smart city activities, and participation of residents, allowing observation of the effects of the implemented solutions.

The selected city is an example of a city, which is evolving towards a smart and sustainable city, whereas the belief of Wroclaw authorities about the important role of public participation in the development of the city has been increasing since the 1990s. This results in the increase in the role of public participation indicated in strategic documents, which results in practical merging of Wroclaw's activities carried out in the scope of smart city and sustainable city development, i.e., striving to become a smart sustainable city. From the point of view of the contribution to the field of research on sustainable and smart cities, it should be noted that the case of Wroclaw can be treated as a catalyst or starting point for research on the coherence of public participation solutions in sustainable city development and smart city programs in regional centers in Poland and Europe.

The structure of presented article reflects the course of performed research works. This article is divided into three main parts. The first one is devoted to the analysis of the scientific achievements 
in the scope of undertaken research problem and the analysis of national and international action plans, particularly:

- Firstly, in order to embed the case study in the broader context, the authors reviewed literature on sustainable development, sustainable urban development and main United Nations (UN) program documents in the scope of sustainable development, taking into account urban development in the context of the role and forms of public participation indicated in these documents.

- Secondly, the authors reviewed national regulations concerning sustainable development and urban development corresponding to the UN strategies and documents, also taking into account the role of public participation indicated in them.

- Thirdly, the authors analyzed the literature regarding the concept of smart cities, taking into account the importance and scope of public participation of this concept, as well as carried out the analysis of connections of the concept of smart city with the concept of sustainable development, particularly in the area of public participation.

The second part was devoted to the analysis of the case study, which included:

- Firstly, the analysis of three subsequent city strategies $(1998,2006,2018)$ in the context of participation and sustainable development.

- Secondly, the analysis of implementation of the smart city concept in Wroclaw (2015-2018), taking into account the significance of participation and sustainable development was done.

- In addition, the work involved analysis of data concerning the participation of residents in subsequent editions of the participatory budget of Wroclaw.

As a consequence, an attempt was made to identify the directions and scope of inclusion of public participation in the concept of sustainable city development, as well as the concept of smart cities, taking into account the national and international conditions.

\section{Analysis of Wroclaw's Strategy from the Years 1998-2018 in the Context of Evolution of the Participation and Sustainable Development}

20 years have passed from the moment of preparation and implementation of the Wroclaw's first development strategy. During this time, two subsequent strategies were developed and adopted, constituting a response to the dynamically changing conditions of the city's functioning. In 1998, less than a year after the flood, which destroyed a large part of the city, the Wroclaw City Council adopted the development strategy entitled Strategy-Wroclaw 2000 Plus [125], which was supposed to be a medium-term document, with the horizon of the first decade of the century. In 2006, the Wroclaw City Council adopted a resolution concerning the update of city's development strategy-Strategy-Wroclaw in the 2020 Plus Perspective [126]. It was mainly focused on the implementation of extensive infrastructure undertakings. This strategy was adopted shortly after Poland's accession to the European Union, therefore the possibility of obtaining EU subsidies had a considerable impact on its shape. The development directions that during that time seemed the most attractive, required verification over time. The answer was the development and adoption of the Development Strategy for the City of Wroclaw until 2030 [127], which occurred in 2018.

In the last 20 years, the above-mentioned documents determined the desired directions of Wroclaw's development, indicating the most important goals that the city faced in this regard, as well as the methods of their implementation. In the context of this study, the emphasis should be mainly placed on two issues-evolution of the significance of the participation in subsequent strategies of Wroclaw and their consideration of issues associated with the sustainable development of the city (Figure S1: Timeline of case study).

\subsection{Wroclaw's Development Strategy Strategy—Wroclaw 2000 Plus}

Wroclaw's development directions defined based on the diagnosed challenges (demographic, political, economic, health, ecological, infrastructural, institutional, to cultural or psychosocial), among 
others, focused on: increase in the number of residents up to approx. one million in the perspective of 2050, taking into account the care for a new generation of Wroclaw residents; supporting economic development; maintaining a significant position in the scope of culture, science and art; development of urban space, including solving communication problems in the city through repair, investment and organizational measures that reconcile the needs of transit and local traffic, as well as individual and collective communication; improving the quality of residents' life, taking into account the issue of the condition of natural environment, health, safety, education, and level of participation in social life, including the actual impact on decisions regarding individual and collective life; changes in the ownership structure; building a sense of identity, belonging and co-responsibility of residents for the city's development, as well as efficient functioning of city authorities.

The above-mentioned directions have been included in the city's mission: "Wroclaw is a meeting place-it is a city that unites", referring to the idea of exchange of values, goods, services, and concepts. The implementation of such formulated mission required the pursuit of six strategic goals:

- developing the Wroclaw's urban functions as a regional metropolis and the center of meetings and exchanges of European significance;

- building the Wroclaw's identity and improving the identification of residents with the city, particularly through science and art;

- creating conditions for the broader economic, civic, and social activity of the residents;

- adapting the urban structures to the aspirations of residents, as well as the specificity of districts and housing estates;

- developing the social fabric of the city, as well as its institutional reconstruction;

- developing the city's technical infrastructure.

Within the Strategy-Wroclaw 2000 Plus [125], a series of strategic programs was formulated, which concerned infrastructure, as well as social problems. One of them was the program entitled "Decentralization", which was aimed at unblocking civic activity through decentralization of the city management and supporting the implementation of local development goals. Among others, this program assumed the following by 2002: (a) changing the city's constitutional concept as a single commune by dividing the city into the city center and other local centers, adapting the functioning of auxiliary units of the city council and city management to such division, granting maximum competences to the neighborhood councils; (b) supporting the emergence process of local activists; (c) opening the city to the initiatives of various groups and communities, aimed at the development of local communities and achievement of group goals; (d) increasing the possibilities of inclusion of various groups into activities for the development of local communities and the city (among others through the revival of committees, councils and organizations, creation of information networks regarding their functioning and a forum for exchanging experiences).

In relation to the challenges associated with striving for sustainable development of Wroclaw, the program entitled "Traffic Jam Elimination in Wrocław" was formulated and it was aimed at creating conditions for efficient, safe and environmentally-friendly transport of people and goods. Among others, the program assumed the following by 2010: construction of the Wroclaw motorway bypass, creation of P\&R parking system on the outskirts of Wroclaw, which was supposed to reduce the car traffic in the city center, modernization of the tramway system and construction of new connections. Equally important was the program entitled "city on the river" aimed at creating the spatial identity of Wroclaw as a city associated with the Oder and its tributaries. Among others, this program focused on: reconstruction and expansion of the Oder boulevards, as well as associated infrastructure of walking routes, implementation of the program transforming the great island (housing estates located on the island) into the area of ecological development and recreation center. The program entitled "Quality of Life" was also extremely important and it focused on the continuous improvement of the quality of life of residents through ecologically motivated investment activities, as well as appropriate social policy. Among other things, it envisioned extension of the spatial offer for recreation, reliability of 
installation and supply of clean drinking water, completion of the city's essential sewerage investments, improvement of city cleanliness, creation of a child-friendly city.

\subsection{Strategy-Wroclaw in the 2020 Plus Perspective}

Mission in the new city strategy has not changed, remaining the unchanged axis of actions. It was indicated that its maintenance is equal to the focus on building a city that provides the possibilities for meetings and exchange of ideas, goods and services, which is attractive and friendly for the residents and visitors, conducive to understanding, responsible, and responsive to the challenges of the future, open to friendly interaction of various cultures and views. The Wroclaw 2020 plus strategy defined the fundamental recommendations and directions of the city's development from a perspective of:

- people (being: health, safety, housing, education: educating citizens, training specialists, work: city's economic policy, places of work, employees, self-fulfilment);

- community (Wroclaw residents: symbolic community, families, neighborhoods and housing estates, academic sphere, culture sphere, social organizations and civic movements, visitors and immigrants);

- external communities;

- $\quad$ space (housing, public, economic, recreation, information, communication);

- $\quad$ self-government (thinking, governing, inspiring, public service).

The above-mentioned areas cover strategic questions concerning the development dilemmas, guidelines regarding changes and proposals for undertaking that support implementation of the strategy.

In relation to the significance of participation in the city's development, the area of 'community' was extremely important, particularly the scope of 'symbolic community', where the following were recognized, among others, as the appropriate directions of actions:

- informing citizens; providing them with knowledge regarding the choices the city is facing;

- developing civic attitudes via debates concerning common issues, promoting the city directed inwards, participation of media focused on discussion;

- positive response to civic initiatives, directing resources in the first place, where you can count on the participation of residents.

However, for such a broadly defined range of indications, the strategy did not determine specific proposals for actions that would enable their effective implementation.

The scopes of 'neighborhoods, housing estates' and 'social organizations and civic movements', which were distinguished in the same area, seem to be equally significant. The first of them formulates the postulates of supporting grassroots initiatives, increasing neighborhood self-governance, building a reciprocal relations between the cities and neighboring communities, maintaining the primacy of the common good over the particular good. The tool aimed at enabling their implementation was supposed to be, among others, a pilot program for the autonomy of the selected housing estate. The second area focused on the possibilities of using the potential of social organizations and civic movements by the city. Among others, it took into account: development of civic self-defense movements and organization of free time, as well as appreciation of initiative groups created for the implementation of a specific project for the common good. Actions that were supposed to enable this in accordance with the strategy, include: preparation and updating a 'map' of civic activity, making public spaces available for civic activity of residents, promoting social and civic activities, particularly among young people.

Despite the lack of a clear placement of the suggested directions of action in the concept of sustainable development, the content analysis allows to identify the adequate recommendations at least in two areas. The first one consists of is 'space':

- in the scope of communication space, the recommendations concerned, among others: relieving the city from transit traffic, elimination of heavy transport from the city center, enforcing environmental 
standards (noise, exhaust gases), soft elimination of passenger cars from the city center, creation of numerous pedestrian zones;

- in the scope of terms of housing space, among others: inhibition of urban sprawl processes, revalorization of tenement houses, revalorization of housing estates on the outskirts of the city, comprehensive improvement of city cleanliness and aesthetics;

- in the scope of public space, among others: caring for historical, representative buildings (sacral, cultural, academic, official), care for incorporating into the city the location and aesthetics of large objects of consumer culture, communication, and architectural adaptation of the city to the needs of people with disabilities;

- in the scope of information space, among others: construction of information environment, deepening intergenerational dialogue, widespread use of Internet techniques in administration, law enforcement, trade, promotion, etc.

At the same time, in the 'self-government' area, the strategy clearly emphasized the responsibility of the authorities and residents for the future of the city, which is characteristic for the idea of sustainable development-“"The city is a deposit of the past for the future. It is necessary to look after it and enrich it, as well as prepare it for the next generation to take over. It is prohibited to ruin and incapacitate the successors by incurring too far-reaching commitments on their behalf" [126]. It is also worth to note that recommendations concerning the strategy include, among others: indication regarding the need to build a social understanding and support for the city's transformations described in it, as well as promote a culture of civic participation.

\subsection{Strategy Wroclaw 2030}

The strategy formulated (for the first time) a vision of the city- "Sustainable development based on the high value of life of the current and future residents, as well as creativity, innovation and entrepreneurship". It was also inspired by the residents, who in the above-mentioned pools determined the preferred priorities of the authorities for the next 10 years. These included: pro-ecological policy, including air protection and increasing the area of green areas ( $45.2 \%$ of respondents), revitalization of degraded city areas (44.9\%), development of public transport (43.6\%) and supporting local entrepreneurship (32.4\%) [127]. The main components of this vision include:

- $\quad$ sustainable development-focusing not only on economic development, but also on social and environmental issues, also in the context of future generations;

- high quality of life-safety, health, comfort of the current and future residents;

- economy based on knowledge-creativity, innovation and entrepreneurship

The overriding goal of the current strategy is the strengthening of solidarity and creativity, increase in the quality of life throughout the city and improvement the Wroclaw's position in the global networks-among others through actions aimed at achieving the status of one of the green capitals of Europe. Verification of the implementation of such formulated strategic goal required the development of a set of measurable indicators. This group includes: life expectancy, results of secondary school final examinations at extended level, place of universities in rankings, GDP per one resident as a percentage of the EU average, place in the Globalization and World Cities Ranking, turnout in neighborhood elections, turnout in local elections, number of days in the year for which the PM10 particulate matter standard is exceeded and the average annual $\mathrm{PM}_{2.5}$ concentration level, percentage of population living up to $300 \mathrm{~m}$ from any green areas.

Actions planned in the strategy have been divided into seven priorities (while maintaining their compliance with the appropriate partial strategies of the city):

- mobility-among others, cohesive public transport system, limiting car traffic in the city center, promoting sustainable mobility, supporting ecological freight transport, developing river transport, developing the agglomeration rail system, developing shared transport systems; 
- quality of the environment and urban space-among others, reduction of $\mathrm{CO}_{2}$ emissions by $30 \%$ by 2030 , investing in environmentally friendly technologies, investing in renewable energy sources on the roofs of public buildings, effective activities aimed at reducing smog, protecting environmentally valuable areas, promoting space sharing, increasing safety in public areas;

- entrepreneurship-e.g., strengthening the position of local enterprises, supporting and promoting local and regional products;

- creative and innovative economy connected with science-e.g., supporting the development of high-tech start-ups, supporting cluster initiatives;

- healthy and active residents-among others, elimination of architectural barriers for people with limited mobility, supporting actions aimed at extending the lives of Wroclaw residents, creating zones of active recreation, expanding the offer in the scope of education, culture, sport and recreation;

- governance - creation of an integrated system for managing urban strategies and urban programs, implementation of recommendations of the functional analysis of Wroclaw housing estates (organic development of grassroots democracy), harmonization of Wroclaw self-government cooperation with the government administration, implementation of the tools of self-government cooperation with non-governmental organizations, further development of the tools of self-government cooperation with universities, increasing the share of residents in city governance (among others through the development and implementation of Wroclaw's participation strategy), developing sub-local (neighborhood) self-government, applying innovative methods of consultation that strengthen civil society, supporting the participation of sub-local self-governments in urban policy consultations, introduction of the new tools for managing urban policies within e-administration (taking into account civil technology, i.e., grassroots civic technologies);

- open city-increasing the access to public services, including the excluded people into the city life, promoting tourist attractions of the city.

From the viewpoint of the purpose of this work, particularly important are the tasks set for the city in the scope of mobility, environmental quality, health of residents, open city and-above all-governance.

\subsection{Smart City Wroclaw}

The idea of creating a modern and responsible city found its expression in the Wroclaw's implementation of the concept of smart city in 2015. The following areas have become its pillars: governance, economy, lifestyle, people, education, mobility, infrastructure and environment (Table 3). The indicated scopes are based on the previously described set of areas highlighted in the report entitled Smart Cities-Ranking of European Medium-Sized Cities [65], which in the case of Wroclaw was extended to include education and infrastructure. They are treated equally and focused on Wroclaw's development in a sustainable manner, while becoming a more and more smart city. In the context of Poland, Wroclaw is not only the one of the precursors of the smart city concept, but also one of the leaders in its implementation.

Efficiency of implementation of the smart city concept has been repeatedly confirmed by awards granted to the city [128]: in 2015-the CINEV Smart Mobility in Smart City award received in Hong Kong for the integration of public transport, in 2016-City of the year over 500,000 residents-award presented during the Smart City Forum for the vision of building Wroclaw as a smart city based on such pillars as: strategy, residents and communication with them, attractiveness of life, as well as development and creation, manifesting among others in openness of data and promotion of start-ups' environment, also in 2016-Public incentives in transport-award presented during the Euro-China Smart Mobility Conference in Shenzhen for modern transport solutions encouraging residents to travel by public transport, in 2016 and 2017-IPMA - award for the Project Management Office for the best managed social project in Poland in the Polish Project Excellence Award competition, in 2018-city of 
the year over 500,000 residents-award within Smart City Forum for innovative solutions in the scope of electromobility and non-cash smart payments, also in 2018- the Green\&Smart City Awards in the Top Level Design category, presented at Smart City Expo in China.

Table 3. Pillars of smart city Wroclaw.

\begin{tabular}{clc}
\hline Pillars & \multicolumn{1}{c}{ Description } & No. of Programs \\
\hline Governance & $\begin{array}{l}\text { Smart-governance includes three elements: policies and strategies, } \\
\text { e-office, and open self-government. Role of the authorities is to organize } \\
\text { and integrate individual elements of smart city. }\end{array}$ & 11 \\
\hline \multirow{2}{*}{ Economy } & $\begin{array}{l}\text { Searching for solutions in the scope of stimulating entrepreneurship } \\
\text { and innovation, increasing productivity and combining local markets } \\
\text { with global markets. }\end{array}$ & 6 \\
\hline Lifestyle & $\begin{array}{l}\text { Initiatives focusing on the needs of present and future generations, } \\
\text { ensuring safe and healthy life, rich cultural, entertainment and housing } \\
\text { offer, wide access to educational, communication, and } \\
\text { service infrastructure. }\end{array}$ & 6 \\
\hline People & $\begin{array}{l}\text { One of the most important aspects of smart city-committed, creative, } \\
\text { and resourceful society, which understands the essence of everyday } \\
\text { sustainable life, constitutes its essential foundation. }\end{array}$ & 6 \\
\hline Education & $\begin{array}{l}\text { Investments in education and knowledge, including education of older } \\
\text { people, elimination of e-excluded and education of entrepreneurship. }\end{array}$ & 6 \\
\hline Mobility & $\begin{array}{l}\text { Mobility consists of three elements: integrated transport system, ICT, } \\
\text { and supporting green transport. }\end{array}$ & 16 \\
\hline Infrastructure & $\begin{array}{l}\text { Modern solutions in the scope of infrastructure are the key to further } \\
\text { development of the city. }\end{array}$ & 6 \\
\hline \multirow{2}{*}{ Environment } & $\begin{array}{l}\text { Sustainable development of the city through appropriate management } \\
\text { of resources, investments in green technologies, public transport, and } \\
\text { pedestrian transport. }\end{array}$ & 3 \\
\hline
\end{tabular}

Source: Own elaboration based on [128].

\subsection{Participation as an Element of the Concept of Smart City Wroclaw}

The key issue of the concept is the interaction between city authorities and citizens, falling within the scope of the "people" area. The active participation of residents, companies and organizations which, in accordance with the smart city 3.0 concept, will be the co-creators of the city, not just passive consumers, was perceived as essential in creating smart Wroclaw. In practice, the idea of participation is implemented in two key programs- "Wroclaw Talks" [129] and Wroclaw Citizen Budget (WBO) [130]. The first of these is a platform that allows conducting broad social consultations, as well as facilitating local meetings with residents, focusing on specific problems. Social consultations between residents and officials allow the former to express their own opinions, better understand the needs of other residents, as well as to ask questions to officials and experts. So far, the following has been carried out within the projects: consultations regarding land development, plan for sustainable urban mobility, location of 'park and ride' parking lots, system of Wroclaw housing estates, the action of making the Wroclaw streets green, city strategy, as well as the Wroclaw Study, forms and principles of WBO operation. The "Wroclaw Talks" website enables the use of free legal assistance, customer guide of the Wroclaw City Hall, but also it allows e.g., to submit a petition or application under within the Micro-grants program, which is a citywide support program for grassroots local initiatives, implemented by residents in cooperation with the Wroclaw Culture Zone and the Umbrella Foundation within one of three paths (for individuals and informal groups, for non-governmental organizations, for informal youth groups). Within this program, the Social Dialogue Groups (GDS) were also created, the idea of which consists of talking, making diagnosis, solving problems and improving the efficiency of activity and cooperation of various groups (residents, NGOs, employees of Wroclaw City Office) in various areas of social life in Wroclaw. 
Compared to other countries, Poland has little experience with using the participatory budget as a governance tool. The first solution, in the form of a pilot project based on the grassroots activities of the Sopot Development Initiative (SIR), was implemented in Sopot in 2011 [103]. In subsequent years, $\mathrm{PB}$ began to be implemented in other cities, which resulted in an increase from approximately 50 PB in 2013 to over 250 in 2018 [104]. Wroclaw was one of the cities that implemented the idea of participatory budget already in 2013. The actual use of PB in Wroclaw as a smart city tool conducive to city sustainable development can be discussed, along with the extension of available financial resources and development of PB procedures allowing the actual wide participation of residents. The very form of participatory budget in Wroclaw has evolved adapting (in subsequent editions of the WBO) to the changing needs of residents and in response to the revealed shortcomings of the earlier solutions [12] (Table 4).

The consequence of the first two years of PB implementation in Wroclaw was the shaping of a PB model that tried to take into account, through the division of neighborhood/regional/area projects, the demographic diversity occurring in the city and resulting in the selection of projects focused only on areas with high population density or concerning larger groups of residents (parents of children attending one school, cyclists). At the same time, by taking into account the submitted proposals in the scope of necessity of supporting small projects within the framework of the $\mathrm{PB}$, mainly regarding the area of improving the quality of life and security, the gradation of the size of projects was introduced. It is also possible to distinguish the important role of leaders as initiators of projects (formally-because a project for PB can be created by a group of residents). In the framework of procedure, a system of consultations and supporting of groups by specialists was developed, as well as discussions regarding the possibility of changes in subsequent editions (evaluations)( Table S1: Participatory budget process in Wroclaw-timeline).

The analysis of data (Table 5) concerning the amount of funds allocated for the participatory budget in 2014-2019 (funds planned for one year in advance) indicates their nominal increase in the studied period, but at the same time a decrease in their share in total city expenditure is visible. There is a very significant increase in the total expenditure of the city per capita visible, which is the result of an active investment policy in subsequent years. After the first period of involvement in PB (2014-2015), also a decline in the interest in voting is visible (particularly, the number of voters aged 18-30 has dropped over $70 \%$, from around 55,000 (2015) to 15,000 (2018)).

From the viewpoint of the directions of use of PB in the city's activities, it should be pointed out that the majority of tasks adopted for implementation were to improve the safety and quality of life of the inhabitants in the broad sense. In subsequent participatory budgets, the city tried to classify projects selected by the residents for implementation into several thematic groups, due to the subject of the project. The classification criteria themselves, and thus assignment of the project to a given group, were not very transparent, however the concept proposed by the city was used in the analysis. In subsequent years, the classification was changed and therefore the presented data constitute a certain unification of used divisions, due to the specificity of financed tasks (Figure 1). At the same time, a database containing a list of selected projects, along with the costs assigned to them, within particular groups of expenditure directions, was not made available. 
Table 4. Evolution of PB in Wroclaw.

\begin{tabular}{|c|c|c|c|c|c|c|}
\hline & 2013 & 2014 & 2015 & 2016 & 2017 & 2018 \\
\hline Pool of funds mln PLN & 3 & 20 & 20 & 25 & 25 & $\begin{array}{l}25+2.5 \text { Green } \mathrm{WBO}+ \\
0.25 \text { monuments }\end{array}$ \\
\hline Restriction on project value & Medium & $\begin{array}{l}\text { Small, } \\
\text { medium, big }\end{array}$ & $\begin{array}{l}\text { Small, } \\
\text { medium, big }\end{array}$ & $\begin{array}{l}\text { Small, medium, big } \\
\text { (entire city) }\end{array}$ & $\begin{array}{l}\text { Small, medium, big } \\
\text { (entire city) }\end{array}$ & $\begin{array}{l}\text { Very small (monuments), small, } \\
\text { medium, big (entire city) }\end{array}$ \\
\hline $\begin{array}{l}\text { Entities authorized for } \\
\text { submission of applications }\end{array}$ & $\begin{array}{c}\text { Groups of } \\
\text { inhabitants, NGOs }\end{array}$ & Leaders & Leaders & Leaders & Leaders & Leaders \\
\hline $\begin{array}{l}\text { Number of votes possible to } \\
\text { be used per } 1 \text { inhabitant }\end{array}$ & 5 & 3 & $\begin{array}{l}3 \text { (one for each } \\
\text { cost threshold) }\end{array}$ & $\begin{array}{l}4 \text { including one per } \\
\text { small and medium } \\
\text { (for areas) }\end{array}$ & $\begin{array}{l}4 \text { including one per } \\
\text { small and medium } \\
\text { (for areas) }\end{array}$ & $\begin{array}{l}5 \text { including one per very small } \\
\text { and one per small and medium } \\
\text { (for areas) }\end{array}$ \\
\hline Territorial area of voting & Entire city & Entire city & Entire city & $\begin{array}{l}14 \\
\text { areas/districts/and } \\
\text { entire city }\end{array}$ & $\begin{array}{l}14 \\
\text { areas/districts/and } \\
\text { entire city }\end{array}$ & $\begin{array}{l}14 \text { areas/districts/and } \\
\text { entire city }\end{array}$ \\
\hline $\begin{array}{l}\text { Minimum number of } \\
\text { votes per project }\end{array}$ & None & None & 100 & 100 & 100 & 100 \\
\hline
\end{tabular}

Source: Own elaboration based on [13,130]. 
Table 5. Share of PB in the city's expenditure (Euro) in subsequent editions of WPB (WBO).

\begin{tabular}{ccccccc}
\hline & $\mathbf{2 0 1 3}$ & $\mathbf{2 0 1 4}$ & $\mathbf{2 0 1 5}$ & $\mathbf{2 0 1 6}$ & $\mathbf{2 0 1 7}$ & $\mathbf{2 0 1 8}$ \\
\hline \% of total expenditures & $0.08 \%$ & $0.51 \%$ & $0.51 \%$ & $0.59 \%$ & $0.55 \%$ & $0.57 \%$ \\
\hline Expenditures per capita & 867.75 & 904.13 & 919.44 & 979.26 & 1048.81 & 1115.58 \\
\hline PB expenditures per capita & 1.10 & 7.32 & 7.29 & 9.10 & 9.09 & 9.99 \\
\hline Number of PB voters & $50,000 *$ & 153,666 & 168,278 & 104,884 & 97,043 & 68,670 \\
\hline$\%$ of inhabitants & $8 \%$ * & $24 \%$ & $26 \%$ & $16 \%$ & $15 \%$ & $11 \%$ \\
\hline & * estimated; Source: own elaboration based on $[130]$. & &
\end{tabular}

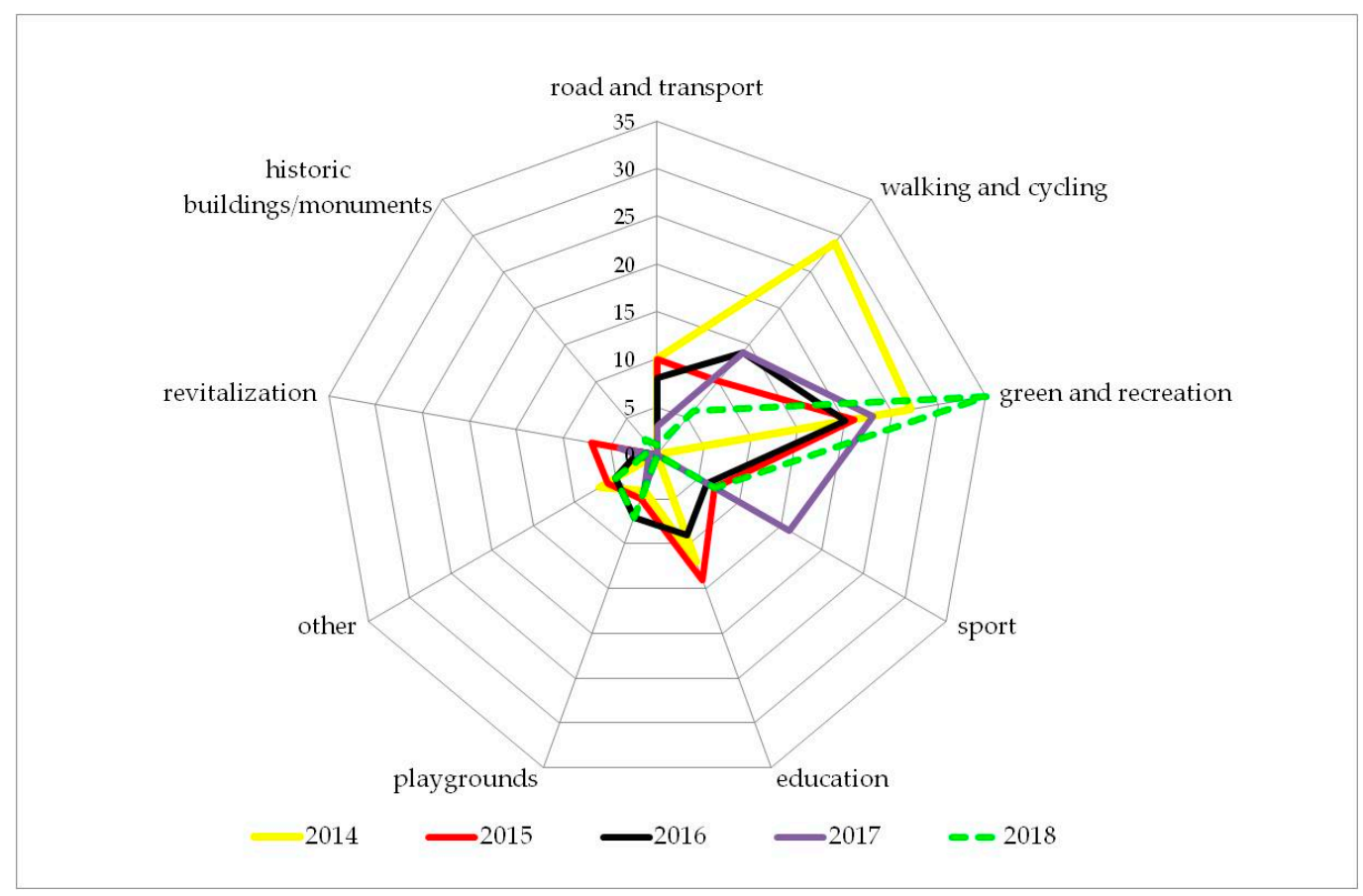

Figure 1. Number of projects selected for implementation due to the direction of expenditure.

Analysis of the value structure of the projects was conducted based on the categorization used by the city authorities [130] (Figure 1). The most numerous group of projects are housing estates projects (in which the pool of funds amounted to over $80 \%$ of the total planned PB), however their number in subsequent years has been constantly decreasing, since the introduction of the division of PB into housing estates-from 77 in 2015 to 59 in 2018. Based on the data concerning the projects selected in the voting, it can be noted that as far as the number of projects is concerned, by far the largest number of selected projects each year concern urban greenery and recreation-i.e., area associated with the improvement of environmental conditions (parks, squares, gardens, plantings). The second group consists of projects associated with the communication system-walking and cycling, as well as road and transport. In this case, the emphasis is put on improving safety by limiting the capacity of streets, as well as by introducing 'green solutions' (bicycle paths, P\&R etc.). Until 2016, the city enabled the financing of generally available public sports facilities of schools and educational institutions, which often translated into initiatives of the residents of housing estates supporting the construction of sports grounds and playgrounds on school grounds.

The last of the frequent directions of PB's investments is the sports infrastructure. To sum up, it can be indicated that the implementation of PB in Wroclaw is focused on satisfying local needs reported by residents in the scope of infrastructure supporting the improvement of the quality of life in the city (green areas, road safety and transport, sport and recreation). 


\subsection{Sustainable Development as an Element of the Concept of Smart City Wroclaw}

Wroclaw functioning according to the smart idea is by definition a city developing in a sustainable manner, in essential areas, such as energy management, mobility, health and its protection, infrastructure, etc. This is reflected in the programs implemented in the city. They can be systematized according to the assignment to individual parts forming the concept of smart city:

- In the 'people' area, it is e.g., the 'city in form' program that promotes a healthy lifestyle and health education of residents. Its goal is to shape pro-health attitudes among the local community. Among others, the educational offer includes: events, conferences, workshops, trainings, physical activities, competitions, and regular initiatives-Health Day in Wroclaw, Wroclaw Days of Health Promotion and Week of Movement. In the framework of this program, a BMI calculator, as well as water demand calculator and calorie-burning calculator were made available to the residents.

- In the 'environment' area, particular importance is assigned to the investments supporting the improvement of energy efficiency, generation of low-emission energy, modernization of infrastructure and education in this scope. The main goal is to govern the city in an ecological, modern, economical, and effective manner. Two main programs include: (1) "KAWKA" —-financial support for the replacement of coal furnace and boiler room with ecological heating; (2) Low Emission Economy Plan (PGN)—strategic document developed for the Wroclaw functional area-Wroclaw and 14 communes.

- In the 'mobility' area, the priority is to move in a convenient, quick and safe manner, with the use of modern technologies, but at the same time in a sustainable manner, i.e., with care for the natural environment. In this area, there is a long list of projects, among others: (1) pilot project 'smart parking', whose aim is to design, install, calibrate and test the system of identification of free parking spaces in the selected area of Wroclaw; (2) Wroclaw System for Charging Electric Vehicles (2011); (3) Wroclaw Challenge-Mobility—a project promoting changes in the behavior of residents in the scope of sustainable urban transport; (4) Smart Trip-the purpose of this project is to conduct research and development works aimed at optimizing the use of transport resources. This program consists of mobile application, functional applications, system for selling tickets of collective transport, parking charging system, loyalty system, big data, sale of tickets to municipal institutions and system for recognizing occupancy of parking spaces; (5) Municipal rental of electric cars in Wroclaw Vozilla—car-sharing system; (6) Wroclaw City Bike (WRM)—self-service urban bike rental system launched in 2011, the first 20 min of rental is free.

- In the 'infrastructure' area, there are two key projects: (1) MAN Wroclaw-project that has been implemented since 2007. It assumed the construction of a public telecommunications network and the construction of a fiber-optic network; (2) Urban Internet-program initiated in 2004, when the first steps associated with the construction of infrastructure allowing free access to the Internet using a radio network were undertaken.

It is necessary to emphasize the compliance of the above-mentioned activities with those declared by Wroclaw residents in the studies on the assumptions of the Wroclaw 2030 Strategy, desirable directions of the government's activities over the next decade, which mainly consisted of urban goals (indicated by nearly $45 \%$ of respondents), i.e., pro-ecological policy, including better air protection and increasing the green areas, revitalization of degraded areas of the city and development of public transport [131]. Such formulated goals emphasize the role of the common good in the scope of creating the quality of residents' life. The second direction of activities, which was indicated by $18-32 \%$ of respondents, were the goals of social development and cohesion, associated with supporting local entrepreneurship, social policy, development of social dialogue, and education [131].

\section{Discussion and Conclusions}

During the studied period, the Wroclaw city authorities developed three strategies for the city development. The conditions such as political, social, demographic situation, resources and growing 
problems of the city had a strong impact on the final shape of the subsequent strategies and guidelines for the action directions. The first strategy was created and adopted during the liquidation of losses after the flood, which occurred in July 1997. Thus, it was dominated by the current problems of the city. Adoption of this strategy at that time had a pragmatic dimension-removal of damages was connected with modernization of the city, whose direction was determined by the strategy, while the strategy became an important tool for gaining the necessary funds for the city, as well as attracting investors. From the viewpoint of this work, it is worth noting several important factors in them. Firstly, a clearly formulated trend of growing citizens' interest in the participation in decision-making processes appeared in the area of political challenges, especially at the local level, with the simultaneous increase in the competences of territorial self-government and its strength in the scope of coordination of local activities. The possibility and necessity to use a computer network to consult, discuss local problems, and even to resolve them through a referendum were also noticed. The second important element appeared in the area of health and ecological challenges-it was noticed that there's a necessity to create a local program of the city's sustainable development, based on the Principles of Wroclaw Ecological Policy, taking into account: environmental protection, active impact on the preservation and reconstruction of diverse ecological systems within the city and its surroundings, shaping the aesthetic urban landscape, preventing the degradation of agricultural land, pro-ecological changes in the residents' lifestyle, taking into account the educational programs, protection against the effects of natural and ecological disasters. Moreover, it was indicated that there is a need to determine a standard of the quality of life for residents and to make it a tool used to carry out local policy. The third important category was psychosocial challenges associated with the need to increase the satisfaction of the Wroclaw's residents from living in their city. Fourthly, in the scope of demographic challenges, the issue appeared concerning the potential problems associated with creating life perspectives for the youth of baby boomers.

Strategy-Wroclaw in the 2020 Plus perspective was de facto an update of the previous strategy, necessary due to the approaching end of the time scope covered by the 1998 strategy, as well as new possibilities resulting from Poland's accession to the European Union. Limiting only to the update resulted from a positive assessment of the activities implemented and continued as part of the previous strategy. As its strategic goal, the new strategy adopted the hand-over of the city to the next generation in a state good enough for it to be the entity and not the subject in the processes of global competition, while human and social capital was indicated as the fundamental factor of the city's development.

Contrary to the previous strategy, the second strategy of Wroclaw did not include any clear indication of determinants associated with the potential of residents to co-decide about its development. There was also no clear indication of the need to include in the city's strategy issues associated with its sustainable development. The potential of residents to participate in the development of the city was indirectly indicated in the group of factors containing the competences and genius loci-there is a reference here to the residents' ability to self-organize and demonstrate initiative, as well as to spontaneous cooperation aimed at the common good.

Dynamic changes in the surroundings resulted in the need to undertake works on a new strategy for Wroclaw. The analysis included in the report entitled Diagnosis of Wroclaw [131] demonstrated that the following cities will have better chances of survival in the future:

- learning cities that will put emphasis on knowledge and development of people (human capital);

- cities that bind strategy of many management areas with the city's main strategy (intellectual capital);

- cities that care about trust (trust capital) and communication (relationship capital) between all users of urban space;

- innovative cities-changing their functional profiles in order to improve the quality of life and to reduce costs, as well as to find new profit opportunities [131].

While using information about trends in the future, the city authorities started the works on the draft of a new strategy Wroclaw 2030 in 2015. The new philosophy of operation was already visible 
at the stage of strategy planning-residents were included in its creation. Firstly, during the period X.2015-VI.2016, 12 open thematic forums were organized, where everyone could expressed their opinion. Secondly-a series of meetings with committees of the city council, neighborhood councils and candidates for councilman were organized. Thirdly-public opinion polls were carried out in 2016 regarding the future of Wroclaw, thus including residents in the process of strategy creation. The results of these polls, proposals collected during forums and determinations of diagnoses were included in its development.

A new mission has become a key element of the strategy-“Wroclaw is a beautiful, wise and rich city-a city that unites and inspires." The priority values included in it were inspired by the results of polls conducted in 2016. By indicating the preferred future profile of the city, the respondents stated that it is particularly important for them that Wroclaw should be the leading center of science and culture, one of the most beautiful cities in Europe, the "Silicon Valley" of Central Europe, a city that attracts tourists and investors, one of the most important transport ports. This new mission also resulted from the analysis of conditions of the city's functioning, among which the key ones included: increasing expectations of residents regarding the quality of life and their impact on decisions, problems associated with the air quality, demography, and aggravating global political situation, probability of a significant reduction in the access to EU funds, probability of changes in the functioning of city self-governments, effective implementation of the previous mission with accompanying increase in GDP and reduction in unemployment (Figure S2: Wroclaw 2030 Strategy goals).

Based on the analysis of including the participation into Wroclaw's development strategies, which is the subject of the study, a clear evolution of the degree and scope of its use can be observed-from single, simple, and unconnected solutions, to separation of governance as one of the priorities of strategic activities and including the participation in its scope.

- The first strategy emphasized the need to support inclusion of groups and environments in social development, however the proposed programs were limited to creating information networks and platforms for exchanging experiences, supporting the process of emergence of the local activists and reviving committees, councils and other organizations in order to support the development of local communities.

- Wroclaw 2020 Strategy indicated three directions of supporting participation: informing citizens, developing citizen and social attitudes and supporting citizen initiatives. However, in practice, the proposed actions were again selective in nature and they were not treated comprehensively.

- A radical change took place in the Wroclaw's third development strategy, in which the main goal was to improve the quality of resident's life, including by increasing their participation in making decisions about the city, in which they live. Unlike the previous ones, Wroclaw 2030 Strategy also emphasized the necessity to create an integrated system of management of urban programs strategies, as well as the role of organic development of grassroots democracy. The proposed programs harmoniously cooperated with these assumptions-they included the planned implementation of the Wroclaw participation strategy, which clearly signals the idea of comprehensive planning and implementation of activities aimed at long-term goals. The change has also occurred in the perception of the necessary instruments-the strategy puts emphasis on the need to use innovative consultation methods and introducing new tools within e-administration (e.g., civil technology).

Analyzing the place of participation in Wroclaw's development strategies in the context of evolution of the participation significance in the analyzed subsequent UN program documents, it can be noticed that there's a high degree of compliance of changes in the meaning of participation and the role of governance between them.

The key moment for the development of public participation in Wroclaw consisted of the years 2013-2015-in this period, the Wroclaw participatory budget (WBO) was launched for the first time, and then the city began to intensely implement the concept of smart city (3.0), making WBO one 
of its key instruments. Within the smart city, two important areas-governance and people-were distinguished. The participatory budget was put in the 'people' area, instead of-in compliance with the theoretical approach-in the 'governance' area. The reasons for this action can be found in the low level of use of ICT in the whole PB procedure-where the main area of ICT use was voting and providing information to residents. ICT was not used to visualize or consult the developed projects. Another form of using ICT in PB was to provide open data regarding the detailed voting results.

The issue of intensifying participation of the Wroclaw residents seems to be significant, because in the studies [131] preceding the formulation of the Wroclaw 2030 strategy, it was diagnosed that $57.9 \%$ of respondents showed the lack of social activity (index of interest in the matters of residence region and the city, as well as activities for the housing estate and the city), while $11.9 \%$ demonstrated the lack of civic activity (covering participation in the last national and European parliament elections, participation in self-government elections and in the municipal referendum). On the other hand, the same studies indicate the significant potential of Wroclaw residents in the scope of activities for the common good- $51.2 \%$ of respondents declared their willingness to engage in activities carried out with other residents, $48 \%$-willingness to be subject to greater rigors and limitations in using cars in urban transport and $46.1 \%$-willingness to be subject to greater rigors and limitations in order to improve the natural environment in the city.

Public participation is an important element of the city's sustainable development (in accordance with the results of literature analysis and the presented research results), as well as significant part of the concept of smart city, which engages the residents in the process of smart co-management (Figure 2).

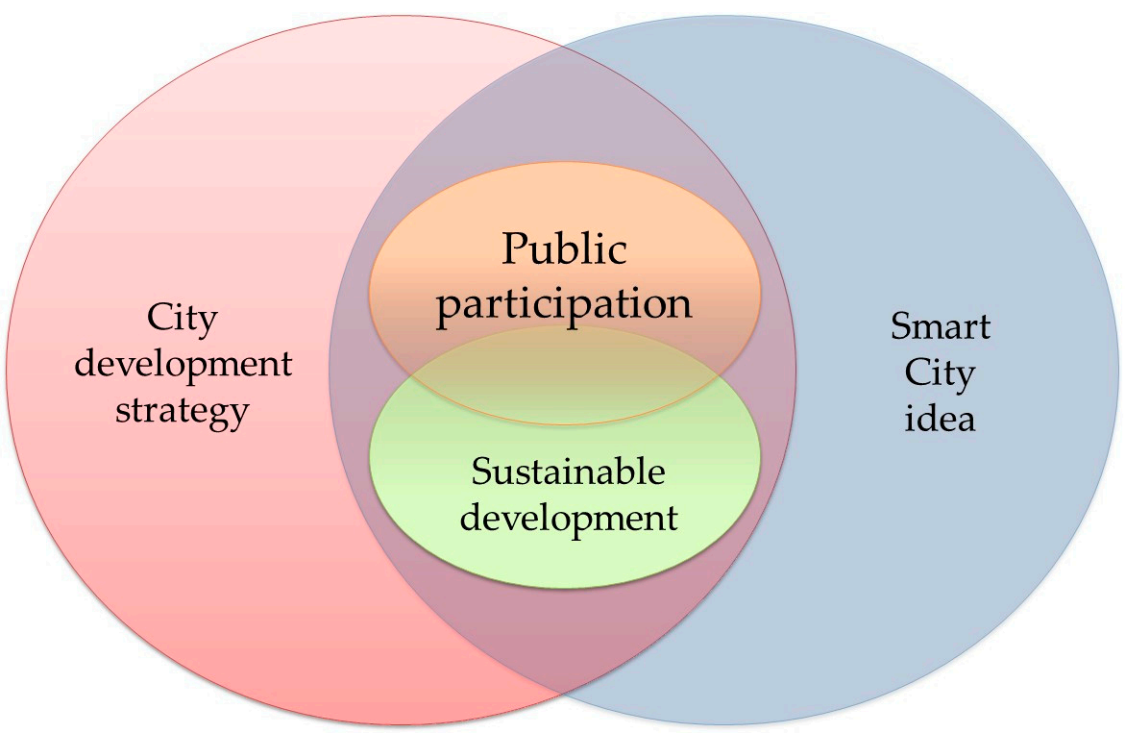

Figure 2. Relationships between Wroclaw development strategy, smart city idea, sustainable development, and public participation.

An important difference is the perception of the scope of participation-in the case of implementation of the city's sustainable development, all of its forms appear (in accordance with the Arnstein's participation ladder), while in the case of smart city the main significance is assigned to the most developed one that provides the residents with a tool for the actual possibilities of co-decision. In the case of Wroclaw, WBO is such tool, however it is worth to consider the wider use of ICT within its framework, which despite the five-year functioning of the budget is still used to a very limited extent. The analysis of Wroclaw's strategic documents from the last 20 years indicates the changing attitude of policy makers towards the city's sustainable development. The first strategy proposed the creation of a local program of sustainable development and it also proposed the programs covering the issues of ecology, transport and quality of life. It can be clearly seen that it is characterized by the inclusion of the residents' participation in the scope of programs associated with the sustainable development of 
the city. During the same period, participation was one of the signalled (but marginalized) elements of Agenda 21. In the second strategy of Wroclaw, there was no indication of the need to include sustainable development issues in it. However, it indicated the directions and activities clearly belonging to this scope (transport, ecology, responsibility for the city's future, encouraging residents to participate in local politics). In the case of the last strategy, sustainable development was included in the vision of the city and became one of the three main directions of activity. Environmental, social, transport, ecological, educational, and health issues gained the rank of priorities, whereas the sustainable development has become one of the elements of the vision and one of the key values for the city.

By comparing the scopes and directions of activities determined by the current Wroclaw development strategy and separately implemented smart city idea, the existence of common areas can be seen associated with the public participation and sustainable development of the city. Having in mind the separation of activities in the scope of smart city and city development strategies among various organizational units, it is necessary to indicate the potential threat of a lack of proper coordination of the activities. Therefore, the communication between decision-making units becomes extremely important (or establishment of a superior unit responsible for the given area), as well as the consistency of documents regulating both issues. The solution adopted by Wroclaw includes two such activities: firstly, it is clearly indicated in the current strategy, with which legal acts and strategies each of the priority areas should be consistent (e.g., governance with conclusions from the Functional Analysis of Wroclaw's Housing Estates of 2017, municipal strategy of participation and strategy of cooperation of the city authorities with non-governmental organizations), secondly-two units were established-Department of Sustainable Development responsible for coordinating urban tasks of design, program or strategic nature, in accordance with the idea of sustainable development, and the Office for Social Participation that carries out and coordinates all activities in the scope of social participation of the city's residents.

The last issue is the decreasing percentage of residents participating in the participatory budgeting process. The results of subsequent editions of WBO indicated that the engagement of residents is decreasing in the scope of creating ideas and participating in voting, particularly in the group of young people (Millennials). The subsequent research should try to diagnose the causes for this state of affairs. The results of previous research $[106,132,133]$ concerning the low inclination of Poles to participate in activities for the benefit of society and low sense of impact on the social matters (Millennials achieved the worst results), let us hypothesize that the potential cause is lack of education in the scope of participation, which translates into the barrier hindering any action ("I do not know, so I do not do") and/or insufficient communication policy, informing and encouraging to participate in the activities of the commune. The participatory budget procedure in Wroclaw is heavily extended in time. The time between submitting the first proposal, revision of it, voting and implementing may take up to two years. Discouragement may be also caused by a significant percentage of projects verified negatively by authorities at the stage of submission. There is also the problem of the extremely small number of consultations with residents concerning submitted (and positively verified) projects.

A number of potential limitations need to be considered. Firstly, the current paper was undoubtedly limited by the complexity of the undertaken problem. The most important limitation lies in the lack of a uniform structure of all strategies, their scope and methods of creation. This could lead to the subjective systematization of gathered information and the possibility of non-intentional omitting or generalizing some less relevant information. Secondly, another limitation was the use of documents mainly generated by one stakeholder in the process-the city, which can result in a distortion of the actual picture of the situation. Thirdly, some of the activities related to the participation of residents in the city activities from before 2015 are not included, either in the analyzed documents or in the information made available by the city, which could have resulted in omitting them in the analysis. Further research should be undertaken to explore, among others, the reasons for participation or non-participation of residents in municipal affairs, methods of communication with city-residents 
and their effectiveness in the governance process, comparative studies with other cities implementing residents' participation both in the smart city projects and sustainable development strategies.

Despite limitations, the conducted research indicates that for the implementation of the SSC concept it would be important to integrate these approaches in order to ensure the full range of residents' participation in accordance with theoretical postulates. The conducted analysis covers, therefore, the mostly unexplored area of research, which is important from the point of view of cities evolution toward a sustainable smart city. The conclusions from the research are also an empirical contribution to the analysis of the changes of cities towards SSC and indicate the need for further, extended research on the problem.

Supplementary Materials: The following are available online at http:/ /www.mdpi.com/2071-1050/11/2/332/s1, Figure S1: Timeline of case study, Figure S2: Wroclaw 2030 Strategy goals, Table S1: Participatory budget process in Wroclaw-timeline.

Author Contributions: Conceptualization, D.B.-O., J.O., and L.S.; Formal analysis, J.O.; Investigation, D.B.-O., J.O., and L.S.; Methodology, D.B.-O., J.O., and L.S.; Resources, D.B.-O. and J.O.; Supervision, D.B.-O.; Visualization, J.O.; Writing-original draft, D.B.-O., J.O., and L.S.; Writing-review and editing, J.O.

Funding: This research received no external funding.

Acknowledgments: This paper is a result of International Scientific Cooperation Program (International Research Team) of Faculty of Economic Sciences, Wroclaw University of Economics and it is a part of internal project Excellence 2019 at Faculty Informatics and Management, University of Hradec Kralove.

Conflicts of Interest: The authors declare no conflict of interest.

\section{References}

1. Boulding, C.; Wampler, B. Voice, Votes, and Resources: Evaluating the Effect of Participatory Democracy on Well-being. World Dev. 2010, 38, 125-135. [CrossRef]

2. Touchton, M.; Wampler, B. Improving Social Well-Being through New Democratic Institutions. Comp. Political Stud. 2014, 47, 1442-1469. [CrossRef]

3. Sintomer, Y.; Herzberg, C.; Rocke, A. Participatory budgeting in Europe: Potentials and challenges. Int. J. Urban Reg. Res. 2008, 32, 164-178. [CrossRef]

4. Sintomer, Y.; Herzberg, C.; Allegretti, G.; Rocke, A. Learning from the South: Participatory Budgeting Worldwide_-An Invitation to Global Cooperation; InWent: Berlin, Germany, 2010.

5. Dias, N. Hope for Democracy. 30 Years of Participatory Budgeting Worldwide; Epopeia Records \& Oficina coordination \& Nelson Dias: Faro, Portugal, 2018; ISBN 978-989-54-1670-7.

6. Avritzer, L. Living under a Democracy: Participation and Its Impact on the Living Conditions of the Poor. Lat. Am. Res. Rev. 2010, 45, 166-185. [CrossRef] [PubMed]

7. The World Bank. Decentralization Briefing Notes; WBI Working Papers; The World Bank: Washington, DC, USA, 1999; p. 116.

8. Reed, M.S. Stakeholder participation for environmental management: A literature review. Biol. Conserv. 2008, 141, 2417-2431. [CrossRef]

9. Voinov, A.; Bousquet, F. Modelling with stakeholders. Environ. Modell. Softw. 2010, 25, 1268-1281. [CrossRef]

10. Beierle, T.C.; Konisky, D.M. Values, conflict, and trust in participatory environmental planning. J. Policy Anal. Manag. 2000, 19, 587-602. [CrossRef]

11. Bifulco, F.; Tregua, M.; Amitrano, C.C. Smart Cities and Innovation: A multi-stakeholder perspective. J. Manag. Mark. 2014, 2, 27-33.

12. Menegat, R. Participatory democracy and sustainable development: Integrated urban environmental management in Porto Alegre, Brazil. Environ. Urban. 2002, 14, 181-206. [CrossRef]

13. Bednarska-Olejniczak, D.; Olejniczak, J. Participatory budget of Wrocław as an element of smart city 3.0 concept. In Proceedings of the 19th International Colloquium on Regional Sciences, Brno, Czech Republic, 15-17 June 2016; pp. 760-766.

14. Żabka, A.; Łapińska, H. Budżet partycypacyjny a rozwój lokalny (Participatory budget vs. local development). Zesz. Nauk. Wyższ. Szk. Finans. Praw. Bielsk. Białej 2014, 4, 36-63. 
15. Burchard-Dziubińska, M. Budżet obywatelski jako narzędzie realizacji rozwoju zrównoważonego na poziomie lokalnym—Przykład Łodzi (Participatory Budget as a Tool for the Implementation of Sustainable Development on Local Level-Example of Lodz). Stud. Prace WNEIZ US 2016, 46, 235-246. [CrossRef]

16. Haaland, C.; van den Bosch, C.K. Challenges and strategies for urban green-space planning in cities undergoing densification: A review. Urban For. Urban Green. 2015, 14, 760-771. [CrossRef]

17. Rogge, N.; Theesfeld, I.; Strassner, C. Social Sustainability through Social Interaction-A National Survey on Community Gardens in Germany. Sustainability 2018, 10, 1085. [CrossRef]

18. Herman, K.; Sbarcea, M.; Panagopoulos, T. Creating Green Space Sustainability through Low-Budget and Upcycling Strategies. Sustainability 2018, 10, 1857. [CrossRef]

19. Scerri, A.; Holden, M. Ecological Modernization or Sustainable Development? Vancouver's Greenest City Action Plan: The City as 'manager' of Ecological Restructuring. J. Environ. Policy Plan. 2014, 16, 261-279. [CrossRef]

20. Buchecker, M.; Hunziker, M.; Kienast, F. Participatory landscape development: Overcoming social barriers to public involvement. Landsc. Urban Plan. 2003, 64, 29-46. [CrossRef]

21. Roberts, I. Leicester environment city: Learning how to make Local Agenda 21, partnerships and participation deliver. Environ. Urban 2000, 12, 9-26. [CrossRef]

22. Kasemir, B.; Jäger, J.; Jaeger, C.C.; Gardner, M.T. (Eds.) Public Participation in Sustainability Science: A Handbook; Cambridge University Press: Cambridge, UK, 2003; ISBN 978-0-521-52144-4.

23. Campbell, S. Green Cities, Growing Cities, Just Cities? Urban Planning and the Contradictions of Sustainable Development. J. Am. Plan. Assoc. 1996, 62, 296-312. [CrossRef]

24. Weymouth, R.; Hartz-Karp, J.; Weymouth, R.; Hartz-Karp, J. Principles for Integrating the Implementation of the Sustainable Development Goals in Cities. Urban Sci. 2018, 2, 77. [CrossRef]

25. Evans, B.; Joas, M.; Sundback, S.; Theobald, K. Governing Sustainable Cities; Routledge: London, UK; Sterling, VA, USA, 2004; ISBN 978-1-84407-169-2.

26. Harrison, C.M.; Munton, R.J.C.; Collins, K. Experimental Discursive Spaces: Policy Processes, Public Participation and the Greater London Authority. Urban Stud. 2004, 41, 903-917. [CrossRef]

27. Smedby, N.; Neij, L. Experiences in urban governance for sustainability: The Constructive Dialogue in Swedish municipalities. J. Clean. Prod. 2013, 50, 148-158. [CrossRef]

28. Gollagher, M.; Hartz-Karp, J.; Gollagher, M.; Hartz-Karp, J. The Role of Deliberative Collaborative Governance in Achieving Sustainable Cities. Sustainability 2013, 5, 2343-2366. [CrossRef]

29. Allegretti, G.; Hartz-Karp, J. Participatory budgeting: a methodological approach to address sustainability challenges. In Methods for Sustainability Research; Hartz-Karp, J., Marinova, D., Eds.; Edward Elgar Publishing: Cheltenham, UK, 2017; pp. 203-216.

30. Boc, E. Cluj-Napoca smart city: More than just technology. In Proceedings of the Transylvanian International Conference in Public Administration, Cluj-Napoca, Romania, 16-17 November 2018; pp. 57-73.

31. Dewalska-Opitek, A. Smart City Concept-The Citizens' Perspective. In Proceedings of the Telematics-Support for Transport; Springer: Berlin/Heidelberg, Germany, 2014; pp. 331-340.

32. Griggs, D.; Stafford-Smith, M.; Gaffney, O.; Rockström, J.; Öhman, M.C.; Shyamsundar, P.; Steffen, W.; Glaser, G.; Kanie, N.; Noble, I. Sustainable development goals for people and planet: Policy. Nature 2013, 495, 305-307. [CrossRef]

33. Robert, K.W.; Parris, T.M.; Leiserowitz, A.A. What is Sustainable Development? Goals, Indicators, Values, and Practice. Environ. Sci. Policy Sustain. Dev. 2005, 47, 8-21. [CrossRef]

34. Stafford-Smith, M.; Griggs, D.; Gaffney, O.; Ullah, F.; Reyers, B.; Kanie, N.; Stigson, B.; Shrivastava, P.; Leach, M.; O'Connell, D. Integration: The key to implementing the Sustainable Development Goals. Sustain. Sci. 2017, 12, 911-919. [CrossRef] [PubMed]

35. Biermann, F.; Kanie, N.; Kim, R.E. Global governance by goal-setting: The novel approach of the UN Sustainable Development Goals. Curr. Opin. Environ. Sustain. 2017, 26-27, 26-31. [CrossRef]

36. Holden, E.; Linnerud, K.; Banister, D. Sustainable development: Our Common Future revisited. Glob. Environ. Chang. 2014, 26, 130-139. [CrossRef]

37. Imperatives, S. Our Common Future; Oxford University Press: Oxford, NY, USA, 1987; ISBN 978-0-19-282080-8.

38. United Nations. United Nations Agenda 21 1992. In Proceedings of the UN Conference on Environment and Development, Rio de Janeiro, Brazil, 3-14 June 1992. 
39. Allegretti, G. Hope for Democracy—25 Years of Participatory Budgeting Worldwide; Dias, N., Ed.; Loco Association: São Brás de Alportel, Portugal, 2015; ISBN 978-972-8262-09-9.

40. United Nations: Millenium Declaration. Available online: http://www.un.org/en/development/ devagenda/millennium.shtml (accessed on 10 November 2018).

41. United Nations Statistics Division-Millennium Indicators. Available online: https://millenniumindicators. un.org/unsd/mi/mi_links.asp (accessed on 10 November 2018).

42. Drexhage, J.; Murphy, D. Sustainable Development: From Brundtland to Rio 2012; United Nations: New York, NY, USA, 2010.

43. Unies, N. Report on the World Summit on Sustainable Development; United Nations: New York, NY, USA, 2002.

44. Redclift, M. Sustainable development (1987-2005): An oxymoron comes of age. Sustain. Dev. 2005, 13, $212-227$. [CrossRef]

45. United Nations. Transforming our World: The 2030 Agenda for Sustainable Development; United Nations: New York, NY, USA, 2015.

46. United Nations. A New Global Partnership: Eradicate Poverty and Transform Economies through Sustainable Development; United Nations: New York, NY, USA, 2013.

47. Tang, H.-T.; Lee, Y.-M. The Making of Sustainable Urban Development: A Synthesis Framework. Sustainability 2016, 8, 492. [CrossRef]

48. Mega, V.; Pedersen, J. Urban Sustainability Indicators; Office for Official Publications of the European Communities: Luxembourg, 1998; ISBN 92-828-4669-5.

49. Girardet, H. Creating Sustainable Cities; Schumacher briefing; Green Books for the Schumacher Society: Dartington, UK, 1999; ISBN 978-1-870098-77-9.

50. Elkin, T.; Duncan, M.; Hillman, M. Reviving the City: Towards Sustainable Urban Development; Continuum International Publishing: London, UK, 1991; ISBN 978-0-905966-83-0.

51. Burgess, R.; Jenks, M. Compact Cities: Sustainable Urban Forms for Developing Countries, 1st ed.; Routledge: London, UK, 2000.

52. European Sustainable Cities - Report of the Expert Group on the Urban Environment; European CommissionDGXI Environment, Nuclear Safety and Civil Protection: Brussels, Belgium, 1996.

53. EU Member States' Ministers responsible for Urban Development. Leipzig Charter on Sustainable European Cities; USEspon: Brussels, Belgium, 2007.

54. Ten Years after the Leipzig Charter; Federal Institute for Research on Building, Urban Affairs and Spatial Developm: Bonn, Germany, 2017.

55. European Commission. Resolution No. 8 of the Council of Ministers of February 14, 2017 on Adopting the Strategy for Responsible Development until 2020 (with a View until 2030); European Commission: Brussels, Belgium, 2017.

56. European Commission. Draft Strategy for Responsible Development until 2020 (with Prospects until 2030); Ministerstwo Rozwoju: Warszawa, Poland, 2016.

57. European Commission. Implementation of the Sustainable Development Goals in Poland, The 2018 National Report; Ministry of Entrepreneurship and Technology: Warsaw, Poland, 2018.

58. Ministerstwo Inwestycji i Rozwoju HUMAN SMART CITIES. Smart Cities Co-Created by Residents. Available online: https: / / www.popt.gov.pl/strony /o-programie/wydarzenia/konkurs-dla-samorzadow-humansmart-cities-inteligentne-miasta-wspoltworzone-przez-mieszkancow / (accessed on 15 November 2018).

59. Ministerstwo Inwestycji i Rozwoju Regulamin Konkursu Human Smart Cities. Available online: https: / / www.popt.gov.pl/media/56932/Regulamin_konkursu_Smart_Cities_final_maj_2018.doc (accessed on 15 November 2018).

60. European Commission. Resolution No. 198 of the Council of Ministers of October 20, 2015 Regarding Adoption of the National Urban Policy; European Commission: Brussels, Belgium, 2015.

61. Graham, S.; Aurigi, A. Urbanising cyberspace? City 1997, 2, 18-39. [CrossRef]

62. Graham, S.; Aurigi, A. Virtual cities, social polarization, and the crisis in urban public space. J. Urban Technol. 1997, 4, 19-52. [CrossRef]

63. Hall, R.E.; Bowerman, B.; Braverman, J.; Taylor, J.; Todosow, H.; Von Wimmersperg, U. The vision of a smart city. In Proceedings of the 2nd International Life Extension Technology Workshop, Paris, France, 28 September 2000.

64. Komninos, N. The architecture of intelligent cities. Intell. Environ. 2006, 6, 53-61. 
65. Giffinger, R.; Fertner, C.; Kramar, H.; Meijers, E.; Fertner, C.; Kramar, H. City-Ranking of European Medium-Sized Cities; Vienna University of Technology: Vienna, Austria, 2007.

66. Caragliu, A.; Bo, C.D.; Nijkamp, P. Smart Cities in Europe. J. Urban Technol. 2011, 18, 65-82. [CrossRef]

67. Anthopoulos, L.; Fitsilis, P. Smart cities and their roles in city competition: A classification. Int. J. Electron. Gov. Res. 2014, 10, 67-81. [CrossRef]

68. ISO/IEC JTC 1. Smart Cities Preliminary Report 2014; Nternational Organization for Standardization: Bern, Switzerland, 2015.

69. Cohen, B. The 3 Generations of Smart Cities. Available online: https://www.fastcompany.com/3047795/ the-3-generations-of-smart-cities (accessed on 15 August 2016).

70. Lytras, M.D.; Visvizi, A. Who Uses Smart City Services and What to Make of It: Toward Interdisciplinary Smart Cities Research. Sustainability 2018, 10, 1998. [CrossRef]

71. Visvizi, A.; Lytras, M.D. Rescaling and refocusing smart cities research: from mega cities to smart villages. Jnl of Science \& Tech Policy Mgmt 2018, 9, 134-145.

72. Visvizi, A.; Lytras, M.D. It's Not a Fad: Smart Cities and Smart Villages Research in European and Global Contexts. Sustainability 2018, 10, 2727. [CrossRef]

73. Anthopoulos, L.; Janssen, M.; Weerakkody, V. A Unified Smart City Model (USCM) for smart city conceptualization and benchmarking. Int. J. e-Gov. Res. 2016, 12, 76-92. [CrossRef]

74. Osborne, D.; Gaebler, T. Reinventing Government: How the Entrepreneurial Spirit Is Transforming the Public Sector; Plume: New York, NY, USA, 1993; ISBN 978-0-452-26942-2.

75. Pierre, J. Models of Urban Governance: The Institutional Dimension of Urban Politics. Urban Aff. Rev. 1999, 34, 372-396. [CrossRef]

76. Stoker, G. Governance as theory: Five propositions. Int. Soc. Sci. J. 1998, 50, 17-28. [CrossRef]

77. Meijer, A.; Bolívar, M.P.R. Governing the smart city: A review of the literature on smart urban governance. Int. Rev. Adm. Sci. 2016, 82, 392-408. [CrossRef]

78. Chourabi, H.; Nam, T.; Walker, S.; Gil-Garcia, J.R.; Mellouli, S.; Nahon, K. Understanding smart cities: An Integrative Framework. In Proceedings of the 45th Hawaii International Conference on System Sciences, Maui, HI, USA, 4-7 January 2012; pp. 2289-2297.

79. Nam, T.; Pardo, T.A.; People, T.; Proc, I. Conceptualizing Smart Sustainable City with Dimensions of Technology, People, and Institutions. In Proceedings of the 12th Annual International Conference on Digital Government Research, College Park, MD, USA, 12-15 June 2011.

80. Olejniczak, J.; Bednarska-Olejniczak, D. Participation of Non-Resident Students in the Creation of Participatory Budget in Wroclaw. Procedia Econ. Financ. 2015, 25, 579-589. [CrossRef]

81. Speer, J. Participatory Governance Reform: A Good Strategy for Increasing Government Responsiveness and Improving Public Services? World Dev. 2012, 40, 2379-2398. [CrossRef]

82. United Nations. Economic and Social Commission for Asia and the Pacific What is Good Governance? United Nations: Brussels, Belgium, 2009.

83. COEFLGR. 12 Principles of Good Governance and European Label of Governance Excellence (ELoGE); Council of Europe: Brussels, Belgium, 2008.

84. Ackerman, J. Co-Governance for Accountability: Beyond "Exit" and "Voice. " World Dev. 2004, 32, 447-463. [CrossRef]

85. Haarstad, H. Constructing the sustainable city: Examining the role of sustainability in the 'smart city' discourse. J. Environ. Policy Plan. 2017, 19, 423-437. [CrossRef]

86. Wiig, A. The empty rhetoric of the smart city: From digital inclusion to economic promotion in Philadelphia. Urban Geogr. 2016, 37, 535-553. [CrossRef]

87. Bakici, T.; Almirall, E.; Wareham, J. A Smart City Initiative: The Case of Barcelona. J. Knowl. Econ. 2013, 4, 135-148. [CrossRef]

88. Trindade, E.P.; Hinnig, M.P.F.; Moreira da Costa, E.; Marques, J.S.; Bastos, R.C.; Yigitcanlar, T. Sustainable development of smart cities: A systematic review of the literature. J. Open Innov. Technol. Mark. Complex. 2017, 3, 11. [CrossRef]

89. Paskaleva, K.; Evans, J.; Martin, C.; Linjordet, T.; Yang, D.; Karvonen, A. Data Governance in the Sustainable Smart City. Informatics 2017, 4, 41. [CrossRef]

90. ITU-T, Smart Sustainable Cities at a Glance. Available online: https:/ /www.itu.int/en/ITU-T/ssc/Pages / info-ssc.aspx (accessed on 12 November 2018). 
91. Martin, C.J.; Evans, J.; Karvonen, A. Smart and sustainable? Five tensions in the visions and practices of the smart-sustainable city in Europe and North America. Technol. Forecast. Soc. Chang. 2018, 133, 269-278. [CrossRef]

92. Bibri, S.E. A foundational framework for smart sustainable city development: Theoretical, disciplinary, and discursive dimensions and their synergies. Sustain. Cities Soc. 2018, 38, 758-794. [CrossRef]

93. Hojer, M.; Wangel, J. Smart Sustainable Cities: Definition and Challenges. In Ict Innovations for Sustainability; Hilty, L.M., Aebischer, B., Eds.; Springer International Publishing Ag: Cham, Switzerland, 2015; Volume 310, pp. 333-349. ISBN 978-3-319-09228-7.

94. D'Auria, A.; Tregua, M.; Vallejo-Martos, M.C. Modern Conceptions of Cities as Smart and Sustainable and Their Commonalities. Sustainability 2018, 10, 2642. [CrossRef]

95. Dhingra, M.; Chattopadhyay, S. Advancing smartness of traditional settlements-case analysis of Indian and Arab old cities. Int. J. Sustain. Built Environ. 2016, 5, 549-563. [CrossRef]

96. Gabrys, J. Programming environments: Environmentality and citizen sensing in the smart city. Environ. Plan. D Soc. Space 2014, 32, 30-48. [CrossRef]

97. Viitanen, J.; Kingston, R. Smart cities and green growth: Outsourcing democratic and environmental resilience to the global technology sector. Environ. Plan. A 2014, 46, 803-819. [CrossRef]

98. Bednarska-Olejniczak, D.; Olejniczak, J. Participatory Budgeting in Poland-Finance And Marketing Selected Issues. In Proceedings of the International Scientific Conference Hradec Economic, Hradec Králové, Czech Republic, 31 January-1 February 2017; pp. 55-67.

99. Roberts, N. Public Deliberation in an Age of Direct Citizen Participation. Am. Rev. Public Adm. 2004, 34, 315-353. [CrossRef]

100. Goodin, R.E.; Dryzek, J.S. Deliberative Impacts: The Macro-Political Uptake of Mini-Publics. Politics Soc. 2006, 34, 219-244. [CrossRef]

101. Hassan, G.F.; El Hefnawi, A.; El Refaie, M. Efficiency of participation in planning. Alex. Eng. J. 2011, 50, 203-212. [CrossRef]

102. Chado, J.; Johar, F.B. Public Participation Efficiency in Traditional Cities of Developing Countries: A Perspective of Urban Development in Bida, Nigeria. Procedia Soc. Behav. Sci. 2016, 219, 185-192. [CrossRef]

103. Beierle, T.C. Using Social Goals to Evaluate Public Participation in Environmental Decisions. Rev. Policy Res. 1999, 16, 75-103. [CrossRef]

104. Cohen, M.; Wiek, A.; Kay, B.; Harlow, J. Aligning Public Participation to Stakeholders' Sustainability Literacy-A Case Study on Sustainable Urban Development in Phoenix, Arizona. Sustainability 2015, 7, 8709-8728. [CrossRef]

105. Arnstein, S.R. A Ladder Of Citizen Participation. J. Am. Inst. Plan. 1969, 35, 216-224. [CrossRef]

106. Bednarska-Olejniczak, D. Public participation of Polish Millenials_Problems of public communication and involvement in municipal affairs. In Proceedings of the 22th International Colloquium on Regional Sciences, Brno, Czech Republic, 31 January-1 February 2017.

107. Connor, D.M. A new ladder of citizen participation. Natl. Civ. Rev. 1988, 77, 249-257. [CrossRef]

108. Wilcox, D. The Guide to Effective Participation; Partnership: Brighton, UK, 1994; ISBN 978-1-870298-00-1.

109. Creighton, J.L. The Public Participation Handbook: Making Better Decisions through Citizen Involvement; Josey Bass; A Wiley Imprint: San Francisco, CA, USA, 2005; ISBN 978-1-118-43704-9.

110. Rowe, G.; Frewer, L.J. A Typology of Public Engagement Mechanisms. Sci. Technol. Hum. Values 2005, 30, 251-290. [CrossRef]

111. IAP2 International Association for Public Participation (IAP2). Available online: https://www.iap2.org/ page/ resources (accessed on 15 November 2018).

112. Anttiroiko, A.-V. City-as-a-Platform: The Rise of Participatory Innovation Platforms in Finnish Cities. Sustainability 2016, 8, 922. [CrossRef]

113. Muñoz, L.A.; Rodríguez Bolívar, M.P. Tools Used by Citizens for Participation in European Smart Cities. In Proceedings of the 19th Annual International Conference on Digital Government Research: Governance in the Data Age, Delft, Netherlands, 30 May-1 June 2018; pp. 92:1-92:2.

114. Svobodova, L. Social Networks and Web Pages Used by Regional Municipalities in the Czech Republic. In Information Systems, Emcis 2017; Themistocleous, M., Morabito, V., Eds.; Springer: Berlin, Germany, 2017; Volume 299, pp. 210-218. ISBN 978-3-319-65930-5. 
115. Srivastava, P.; Mostafavi, A. Challenges and Opportunities of Crowdsourcing and Participatory Planning in Developing Infrastructure Systems of Smart Cities. Infrastructures 2018, 3, 51. [CrossRef]

116. Wampler, B. A guide to Participatory Budgeting. In Participatory Budgeting; Shah, A., Ed.; Public Sector Governance and Accountability; The World Bank: Washington, DC, USA, 2007; pp. 21-54. ISBN 978-0-8213-6923-4.

117. Goldfrank, B. The politics of deepening local democracy-Decentralization, party institutionalization, and participation. Comp. Politics 2007, 39, 147-168.

118. Shah, A. Participatory Budgeting; World Bank: Washington, DC, USA, 2007; ISBN 978-0-8213-6923-4.

119. Bednarska-Olejniczak, D.; Olejniczak, J. Participatory Budgeting in Poland in 2013-2018-Six Years of Experiences and Directions of Changes. In Hope for Democracy. 30 Years of Participatory Budgeting Worldwide; Dias, N., Ed.; 2018; pp. 337-354. Available online: http://npms.cfh.ufsc.br/files/2018/09/hope_for_ democracy_-_digital.pdf (accessed on 10 November 2018).

120. Ustawa z dnia 8 marca 1990 r. o samorządzie gminnym, Dz.U.1990.16.95 (Local Government Act). 1990. Available online: http:/ / prawo.sejm.gov.pl/isap.nsf/download.xsp/WDU19900160095/U/D19900095Lj. pdf (accessed on 12 October 2018).

121. Bansal, P. Inducing Frame-Breaking Insights through Qualitative Research. Corp. Gov. Int. Rev. 2013, 21, 127-130. [CrossRef]

122. Flyvbjerg, B. Five Misunderstandings About Case-Study Research. Qual. Inq. 2006, 12, 219-245. [CrossRef]

123. Second Tier Cities Matter; EPSON: Luxembourg, 2016.

124. Książek, S.; Suszczewicz, M. City profile: Wrocław. Cities 2017, 65, 51-65. [CrossRef]

125. Rada Miejska Wrocławia Wrocław City Council Resolution on the adoption of the Wrocław Development Strategy “Strategia-Wrocław 2000 Plus" 1998. Available online: http:/ / uchwaly.um.wroc.pl/uchwala.aspx? numer=LII/765/98 (accessed on 12 October 2018).

126. Rada Miejska Wrocławia Wrocław City Council Resolution on adoption of Wrocław's development strategy "Strategia-Wrocław w perspektywie 2020 plus" 2006. Available online: http:/ / uchwaly.um.wroc.pl/uchwala. aspx?numer=LIV/3250/06 (accessed on 12 October 2018).

127. Rada Miejska Wrocławia Wrocław City Council Resolution on Wrocław's development strategy under the name "Strategia Wrocław 2030" 2018. Available online: http:/ / uchwaly.um.wroc.pl/uchwala.aspx?numer= LI/1193/18 (accessed on 6 November 2018).

128. SmartCity Wrocław. Available online: https://www.wroclaw.pl/smartcity/ (accessed on 10 October 2018).

129. Wrocław Rozmawia. Available online: https://www.wroclaw.pl/rozmawia/ (accessed on 12 October 2018).

130. Office for Social Participation of the City of Wroclaw WBO. Available online: http:/ /www.wroclaw.pl/ rozmawia/wroclawski-budzet-obywatelski (accessed on 30 October 2018).

131. Pluta, J. Mieszkańcy na Temat Bieżacej Oceny Potencjału Wrocławia i Strategii Rozwojowych Miasta (Residents on the Subject of Current Assessment of Wroclaw's Potential and Development Strategies of the City); Wroclaw City Council: Wrocław, Poland, 2016.

132. Czapiński, J.; Panek, T. (Eds.) Diagnoza Społeczna 2015. Warunki i Jakość życia Polaków Social Diagnosis 2015. (The Conditions and Quality of Poles' Lives); Rada Monitoringu Społecznego: Warszawa, Poland, 2015.

133. CBOS. Poczucie Wptywu na Sprawy Publiczne (The Sense of Influence on Public Affairs); Centrum Badania Opinii Publicznej (CBOS): Warszawa, Poland, 2017.

(C) 2019 by the authors. Licensee MDPI, Basel, Switzerland. This article is an open access article distributed under the terms and conditions of the Creative Commons Attribution (CC BY) license (http://creativecommons.org/licenses/by/4.0/). 